University of Nebraska - Lincoln

DigitalCommons@University of Nebraska - Lincoln

\title{
High Resolution Paleoceanography of the Guaymas Basin, Gulf of California, During the Past 15000 Years
}

John A. Barron

USGS, MS910, 345 Middleçeld Road, Menlo Park, CA 94025, USA

David Bukry

USGS, MS910, 345 Middleçeld Road, Menlo Park, CA 94025, USA

James L. Bischoff

USGS, MS910, 345 Middleçeld Road, Menlo Park, CA 94025, USA

Follow this and additional works at: https://digitalcommons.unl.edu/usgsstaffpub

Part of the Earth Sciences Commons

Barron, John A.; Bukry, David; and Bischoff, James L., "High Resolution Paleoceanography of the Guaymas Basin, Gulf of California, During the Past 15000 Years" (2004). USGS Staff -- Published Research. 264.

https://digitalcommons.unl.edu/usgsstaffpub/264

This Article is brought to you for free and open access by the US Geological Survey at DigitalCommons@University of Nebraska - Lincoln. It has been accepted for inclusion in USGS Staff -- Published Research by an authorized administrator of DigitalCommons@University of Nebraska - Lincoln. 


\title{
High resolution paleoceanography of the Guaymas Basin, Gulf of California, during the past 15000 years
}

\author{
John A. Barron*, David Bukry, James L. Bischoff \\ USGS, MS910, 345 Middlefield Road, Menlo Park, CA 94025, USA
}

Received 17 February 2003; received in revised form 7 May 2003; accepted 9 May 2003

\begin{abstract}
Deep Sea Drilling Project Site $480\left(27^{\circ} 54.10^{\prime} \mathrm{N}, 111^{\circ} 39.34^{\prime} \mathrm{W} ; 655 \mathrm{~m}\right.$ water depth) contains a high resolution record of paleoceanographic change of the past 15000 years for the Guaymas Basin, a region of very high diatom productivity within the central Gulf of California. Analyses of diatoms and silicoflagellates were completed on samples spaced every 40-50 yr, whereas ICP-AES geochemical analyses were completed on alternate samples (sample spacing 80-100 yr). The Bølling-Allerød interval (14.6-12.9 ka) (note, ka refers to 1000 calendar years BP throughout this report) is characterized by an increase in biogenic silica and a decline in calcium carbonate relative to surrounding intervals, suggesting conditions somewhat similar to those of today. The Younger Dryas event (12.9-11.6 ka) is marked by a major drop in biogenic silica and an increase in calcium carbonate. Increasing relative percentage contributions of Azpeitia nodulifera and Dictyocha perlaevis (a tropical diatom and silicoflagellate, respectively) and reduced numbers of the silicoflagellate Octactis pulchra are supportive of reduced upwelling of nutrient-rich waters. Between 10.6 and $10.0 \mathrm{ka}$, calcium carbonate and A. nodulifera abruptly decline at DSDP 480, while Roperia tesselata, a diatom indicative of winter upwelling in the modern-day Gulf, increases sharply in numbers. A nearly coincident increase in the silicoflagellate Dictyocha stapedia suggests that waters above DSDP 480 were more similar to the cooler and slightly more saline waters of the northern Gulf during much of the early and middle parts of the Holocene $(\sim 10$ to $3.2 \mathrm{ka})$. At about $6.2 \mathrm{ka}$ a stepwise increase in biogenic silica and the reappearance of the tropical diatom A. nodulifera marks a major change in oceanographic conditions in the Gulf. A winter shift to more northwesterly winds may have occurred at this time along with the onset of periodic northward excursions (El Niño-driven?) of the North Equatorial Countercurrent during the summer. Beginning between 2.8 and $2.4 \mathrm{ka}$, the amplitude of biogenic silica and $\mathrm{wt}^{\%} \mathrm{Fe}, \mathrm{Al}$, and $\mathrm{Ti}$ (proxies of terrigenous input) increase, possibly reflecting intensification of ENSO cycles and the establishment of modern oceanographic conditions in the Gulf. Increased numbers of $O$. pulchra after $2.8 \mathrm{ka}$ suggest enhanced spring upwelling.
\end{abstract}

(C) 2003 Elsevier B.V. All rights reserved.

Keywords: Holocene; Gulf of California; upwelling; diatoms; silicoflagellates; productivity

\section{Introduction}

* Corresponding author. Tel.: +1-650-329-4971; Fax: +1-650-329-5203.

E-mail address: jbarron@usgs.gov (J.A. Barron).

\subsection{Modern climatology}

The climate of the Gulf of California (referred

0377-8398/03/\$ - see front matter (C) 2003 Elsevier B.V. All rights reserved. doi:10.1016/S0377-8398(03)00071-9

This article is a U.S. government work, and is not subject to copyright in the United States. 

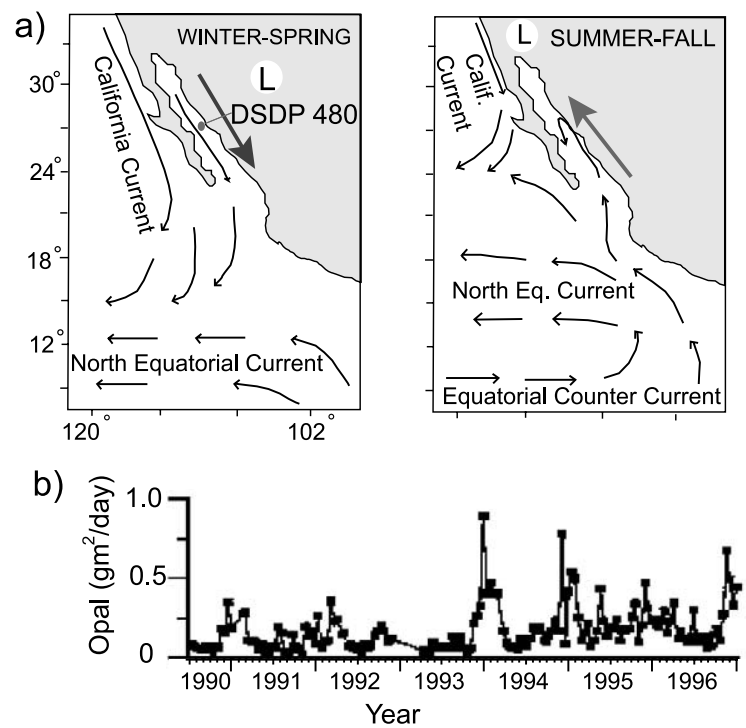

Fig. 1. Modern Gulf climatology (a) and (b) Guaymas Basin sediment trap records of opal flux after (Thunell, 1998). (a) Winter-spring upwelling conditions coincide with strong NW surface winds (arrow), an atmospheric low over the mainland to the northeast, and a weakened equatorial gyre. Oligotrophic summer conditions are marked by a strengthened equatorial gyre, atmospheric low to the northwest, and a reversal of wind direction (after Pride et al., 1999). (b) The peak opal flux occurs in November-December, while that of the summer period (June-September) has the lowest flux.

to as the 'Gulf' throughout this paper) region is divided into a mid-latitude, winter phase and a subtropical, summer phase (Fig. 1). During the winter, prevailing surface winds are northwesterly, along the mean pressure gradient, causing an overturn of the water column, upwelling of nutrients and enhanced phytoplankton production (Fig. 1a). This pattern is punctuated by brief southerly winds lasting a few days caused by an anticyclone that often resides over the southwestern United States (Bandon-Dangon et al., 1991). During the summer, winds blow steadily from the south, resulting in a monsoonal climate of increased rainfall and reduced primary productivity (Fig. 1a).

Sediment trap studies in the Guaymas and Carmen basins (Thunell et al., 1994, 1996; Thunell, 1998) reveal that the peak flux in biogenic silica, which is overwhelmingly diatoms, occurs in November and December, coincident with the onset of northwest winds (Fig. 1). This late fall peak in opal flux corresponds with the 'fall dump' of Kemp et al. (2000), the sedimentation of a longlived episode of production that is triggered by late fall mixing of the water column. True coastal upwelling conditions do not develop in the Gulf until late winter-spring. Thunell et al. (1994) observe that the magnitude of this late winter-spring flux is relatively small, compared to that of the late fall, and they speculate that grazing by zooplankton might be responsible. This early spring peak in opal production coincides with a period of coastal upwelling, which is stronger along the mainland coast than it is off the coast of Baja California (Santamaria-del-Angel et al., 1994). Such conditions produce anoxic bottom conditions and some of the most rapidly accumulating biogenic sediments in the world.

Thunell et al. (1994) noted that during the 1991/1992 El Niño, the period of warm sea surface temperatures (SSTs), which characterizes the summer in the Gulf, extended through December, and they observed that winter SSTs in early 1992 were several degrees warmer than usual. As a result, the high terrigenous fluxes which typify the summer-early fall period, may extend into the winter during El Niño years, as they did in 1992. Based on a 6-yr series of sediment trap samples (1991-1996), Thunell (1998) concluded that primary productivity in the Guaymas Basin was higher during non-El Niño years (Fig. 1b).

\subsection{Modern diatom and silicoflagellate assemblages}

Sancetta (1995) studied seasonal diatom flux patterns in sediment traps from the eastern side of the Guaymas Basin and the western side of the Carmen Basin over a 2-yr period. She concluded that patterns of primary production were uniform across the central Gulf during all seasons of the year, with the annual maximum in diatom production occurring in the winter. Sancetta (1995) remarked that only the hyalochaete Chaetoceros species demonstrated a clear seasonal cycle, with maximum flux during the spring.

Murray and Schrader (1983) studied plankton and surface samples from the Gulf of California in order to determine the present-day geographic 
distribution of silicoflagellate taxa and to relate assemblages to various water masses.

The studies of Murray and Schrader (1983) along with earlier studies by Poelchau (1976) reveal the environmental preferences of silicoflagellate taxa. Tropical silicoflagellates include Dictyocha calida, D. calida ampliata, (grouped with D. calida in Poelchau, 1976), and D. perlaevis (D. sp. A and D. sp. B of Murray and Schrader, 1983). Dictyocha stapedia, (D. messanensis of Murray and Schrader, 1983), is a cosmopolitan form that dominates the silicoflagellate assemblage at Pacific stations west of the Baja California peninsula as well as assemblages in the northern Gulf (Schrader et al., 1986). Dictyocha aculeata is associated with the modern California Current. Octactis pulchra is indicative of high levels of primary productivity in surface waters and is most common in the central Gulf, supporting the observations of Schrader and Baumgartner (1983) who use $O$. pulchra as the main component of a productivity factor.

\subsection{Previous paleoceanographic studies}

Previous studies of the deglacial and Holocene climatic history of the central Gulf of California have largely been concentrated on either DSDP $480 \quad\left(27^{\circ} 54.10^{\prime} \mathrm{N}, 111^{\circ} 39.34^{\prime} \mathrm{W} ; 655 \mathrm{~m}\right.$ water depth) in the eastern Guaymas Basin or piston core JPC-56 $\left(27^{\circ} 28.16^{\prime} \mathrm{N}, 112^{\circ} 6.26^{\prime} \mathrm{W}\right.$; water depth $818 \mathrm{~m}$ ) in the western part of the Guaymas Basin (Fig. 2).

Both Shackleton and Hall (1982) and Keigwin and Jones (1990) identified deglacial oscillations in the $\delta^{18} \mathrm{O}$ of benthic foraminifera at DSDP 480. Keigwin and Jones (1990) speculated that isotopic minima might reflect pluvial events in the American Southwest, and maxima might reflect local cooling. Keigwin and Jones (1990) also proposed that changes from laminated (or varved) to non-laminated sediments during the glacial and Younger Dryas (YD) intervals were caused by increasing oxygen content of Pacific intermediate waters.

Sancetta (1995) used her sediment trap data to interpret downcore diatom data of the past 15000 years in core JPC-56 in the western Guaymas Ba-

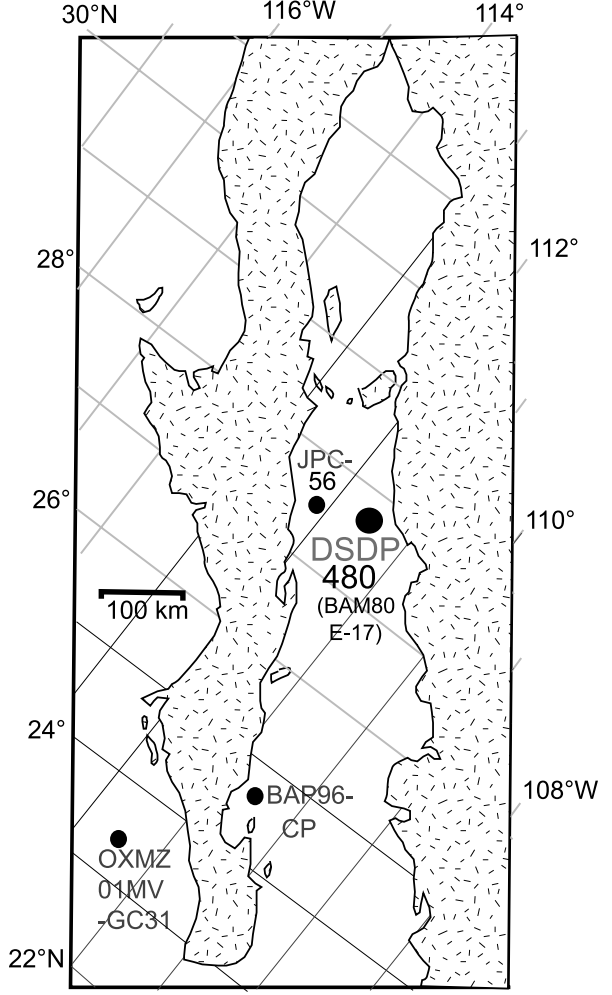

Fig. 2. Location of DSDP Site 480 and nearby Kasten core BAM80 E-17 in the eastern Guaymas Basin and locations of other cores discussed.

sin. She argued that during the late Glacial period, prior to the Bølling-Allerød interval ( $>14.6$ $\mathrm{ka}$ ), total annual production was low, with minimal production during winter and low production during spring. Subtropical waters were consistently present in the Gulf, winter-spring northwesterly winds were weak or non-existent. During the Bølling-Allerød (14.6-12.9 ka), conditions were more like those of today, with moderately high winter and spring production resulting from northwest winds, and relatively common incursions of subtropical waters into the Gulf during the summer. The YD saw a slackening of winterspring northwesterly winds, declining total production, and enhanced El Niño-like conditions. Sancetta (1995) suggested that low spring production persisted into the Holocene, while winter winds gradually increased, peaking in the middle part of the Holocene. The scarcity of Azpeitia nodulifera between $\sim 11.0$ and $5.0 \mathrm{ka}$, suggested 
to Sancetta (1995) that El Niño conditions had become less common. She speculated that at some point in the middle Holocene, 'there was a rapid shift to present conditions, with northwesterly winds persisting into spring, resulting in a more even balance of winter and spring production'.

Pride et al. (1999) studied the nitrogen isotopic composition of organic matter $\left(\delta^{15} \mathrm{~N}_{\text {org }}\right)$ and opal content from a composite section of the past 16000 years made up of piston core JC-56 and gravity core GGC-55 $\left(28^{\circ} 28.22^{\prime} \mathrm{N}, 112^{\circ} 6.33^{\prime} \mathrm{W}\right.$; water depth $820 \mathrm{~m}$ ) in the western Guaymas Basin. They reported that homogeneous sediment with relatively low $\delta^{15} \mathrm{~N}_{\text {org }}$ values and low opal content were deposited at the end of the last glacial period, during $\mathrm{YD}$, and during the middle and late Holocene in the western Guaymas Basin. The Bølling-Allerød and early Holocene, on the other hand, were characterized by laminated sediment, very high $\delta^{15} \mathrm{~N}_{\text {org }}$ values, and relatively high opal accumulation rates. They attributed these differences to changes in the extent of suboxic subsurface waters due to variations in the strength of upwelling associated with vertical mixing and/ or the latitudinal position of the Intertropical Convergence Zone. Updated estimates of the calendar ages of these two cores provided by Keigwin (2002) reveal that the sediment accumulation rates in these cores were high during the late deglacial and Bølling-Allerød $(>200 \mathrm{~m} / \mathrm{kyr})$ and again during the earliest Holocene interval between $\sim 11.6$ and $10.0 \mathrm{ka}(\sim 245 \mathrm{~m} / \mathrm{kyr})$, but they were reduced during the YD $(\sim 92 \mathrm{~m} / \mathrm{kyr})$ and during the Holocene after $10.0 \mathrm{ka}(\sim 86 \mathrm{~m} /$ kyr).

Keigwin (2002) studied the oxygen and carbon isotopes of planktonic and benthic foraminifera in JPC-56. He found pronounced lowering of the $\delta^{13} \mathrm{C}$ of Planulina ariminensis, Neogloboquadrina pachyderma, and Globigerina bulloides at about $9.5 \mathrm{ka}$ in JPC-56, roughly coincidental with an approximately threefold decrease upsection in sediment accumulation rates. He noted that this 'Gulf event is recorded in three samples over a 60$\mathrm{cm}$ interval (total of eight analyses), so it actually may be multiple events'. Keigwin (2002) further pointed out that low $\delta^{13} \mathrm{C}$ after $9.5 \mathrm{ka}$ is not as- sociated with $\delta^{18} \mathrm{O}$ evidence for warmer bottom waters and that other benthic foraminiferal species in the Guaymas Basin do not record anomalously low $\delta^{13} \mathrm{C}$ at this time.

Douglas et al. (2002) completed high resolution analyses on the sediment record of the past 7700 years of Kasten core BAP96-CP from the Alfonso Basin in the southern Gulf (Fig. 2). They argued that between 7.4 and 3.0 ka climate in the Gulf was warmer and wetter with lower primary productivity. Douglas et al. (2002) found that these terrigenous- and carbonate-rich sediments displayed cycles of variability every $\sim 1480 \mathrm{yr}, 900$ $\mathrm{yr}, 350 \mathrm{yr}, 150 \mathrm{yr}$ and $100 \mathrm{yr}$, which they related to climate and oceanography. For example, they suggested that the periods of $150 \mathrm{yr}$ and $350 \mathrm{yr}$ were related to productivity pulses.

Barron et al. (2003a) published a high resolution study of the past 2000 years (samples every $\sim 37 \mathrm{yr}$ ) of the diatoms, silicoflagellates, and geochemistry for Kasten Core BAM80 E-17 $\left(27.920^{\circ} \mathrm{N}\right.$ and $111.610^{\circ} \mathrm{W} ; 620 \mathrm{~m}$ water depth), which was taken very close to DSDP 480 in the western Guaymas Basin. They observed that roughly every $200 \mathrm{yr}$ intervals enriched in diatoms alternate with intervals characterized by higher terrigenous material and total organic carbon (TOC), suggesting that solar forcing was important. Barron et al. (2003a) noted that the record of percent biogenic silica was remarkably similar to the radiocarbon production curve, with increased diatom production occurring during solar minima. They suggested that solar minima coincided with an increase in the strength and/or duration of late fall/winter northwest winds blowing down the Gulf due to atmospheric cooling above northwest Mexico.

Barron et al. (2003a) also observed that a prolonged interval of dramatically warmer SSTs, marked by a twofold increase (above normal background fluctuations) in the relative abundance of the tropical diatom Azpeitia nodulifera, occurs between AD 910 and 1140, corresponding to the Medieval Warm Period. This interval was interrupted by a brief period (AD sim;1020 1100 ) of reduced $A$. nodulifera and enhanced diatom production.

These previous studies as well as our analysis 
(Barron et al., 2003a) of the past 2000 years of BAM80 E-17 suggest that a high resolution study of the latest Pleistocene and Holocene record of DSDP 480 using geochemistry, diatoms, and silicoflagellates would reveal much about the paleoceanography and paleoclimatology of the central Gulf of California.

\section{Materials and methods}

\subsection{Sampling}

Samples were taken at $5-\mathrm{cm}$ intervals from Cores 1 through 3 of DSDP 480 (0-13.71 m below seafloor (mbsf) according to Shipboard Scientific Party, 1982). The approximate 1-cm thickness of each sample and the varved nature of the sediments mean that each sample represents on the order of seven years of deposition. Samples were taken vertically across the varves and homogeneous splits were used for siliceous microfossil and geochemical studies.

\subsection{Geochemistry}

Bulk ICP-AES geochemical analyses were performed on alternate samples (or 10-cm intervals) following total sample dissolution after metaborate fusion. The following elements were analyzed: $\mathrm{Na}, \mathrm{Mg}, \mathrm{Al}, \mathrm{Si}, \mathrm{P}, \mathrm{K}, \mathrm{Ca}, \mathrm{Ti}, \mathrm{Cr}, \mathrm{Mn}$, $\mathrm{Fe}, \mathrm{Sr}, \mathrm{Y}, \mathrm{Zr}, \mathrm{Nb}$, and $\mathrm{Ba}$. $\mathrm{Wt} \%$ biogenic $\mathrm{Si}$ was estimated from the analyses by using the $\mathrm{Si} / \mathrm{Al}$ ratio to factor out the terrigenous (non-biogenic) silica. Although the bulk of $\mathrm{Si}$ in the core is biogenic, an important fraction comes from terrigenous alumino-silicate material. The homogeneity of the terrigenous material, however, allows its contribution to the total silica to be subtracted. The linear relationship between $\mathrm{Ti}$ and $\mathrm{Al}$ $\left(r^{2}=0.855\right)$ points to two important facts: (1) that all the $\mathrm{Al}$ and $\mathrm{Ti}$ are exclusively in the same terrigenous component of the sediment, and (2) that the terrigenous component is homogeneous throughout the core. Moreover, the Ti/A/ ratio is very close to that of Pacific pelagic clay (Ppc; Bischoff et al., 1979), the terrigenous material typical of the open ocean. Because the Ti/Al ratio is approximately constant, we conclude that the $\mathrm{Si} / \mathrm{Al}$ ratio is likewise approximately constant. For a first approximation we assume the $\mathrm{Si} / \mathrm{Al}$ ratio to be equal to that of $\mathrm{Ppc}$, or 3.30. This allows us to subtract the terrigenous contribution to the sediment based on the $\mathrm{Al}$ content of each sample. Because the biogenic fraction dominates over the terrigenous material, a small error in the assumed $\mathrm{Si} / \mathrm{Al}$ ratio will not have a significant effect on the estimated amount of biogenic Si. Calcium carbonate percentage was determined for the same samples by acidification and measurement of evolved $\mathrm{CO}_{2}$ by coulometry. Total carbon was determined on a separate aliquot by combustion at $1000^{\circ} \mathrm{C}$ and coulometric measurement of evolved $\mathrm{CO}_{2}$. Organic carbon was calculated as the difference between total carbon and $\mathrm{CaCO}_{3}$ carbon.

\subsection{Diatoms}

Following Sancetta (1995), counts of diatoms were made at $500 \times$, ignoring Chaetoceros spores and Thalassionema nitzschioides that dominate the sediment assemblages and mask subtle seasonal changes that occur in less common diatom taxa. In addition, small and delicate taxa (Fragilariopsis, Rhizosolenia, Thalassiosira) were not counted in order to reduce bias caused by differential dissolution and differential settling of pipetted samples. Large centric diatoms demonstrating clear environmental preferences according to the sediment trap studies of Sancetta (1995; written commun., 2001), and sediment fabric studies of Pike and Kemp (1997) and Kemp et al. (2000) were counted. These included Actinocyclus curvatulus, A. octonarius, Actinoptychus spp., Azpeitia nodulifera, Coscinodiscus spp. (mainly $C$. radiatus but also large-diameter forms such as $C$. asteromphalus, C. granii, and C. oculus-iridis), Cyclotella spp. (mainly C. littoralis), Roperia tesselata, and Stephanopyxis palmeriana. At least 200 diatoms per sample were counted while making random traverses across the microscope slide at $500 \times$.

\subsection{Silicoflagellates}

Silicoflagellate slides were systematically 
tracked across an upper, middle and lower area to obtain a representative count of 200 specimens for the samples. Counts were typically made at magnification $250 \times$, with $500 \times$ used in checking questionable identifications. All whole specimens and half specimens with apical structures intact, were counted. Smaller fragments were not counted.

Taxa counted included those tabulated by Murray and Schrader (1983), although their taxonomy has been updated and further subdivisions have been recognized. Additional taxa tabulated include Dictyocha calida ampliata, a tropical form, that was grouped with $D$. calida by Poelchau (1976) and D. aspinosa, a cosmopolitan form, that was grouped with $D$. stapedia by Poelchau (1976). Dictyocha sp. A and B of Murray and Schrader (1983) are tabulated as D. perlaevis, although the $D$. sp. $A$ forms can be distinguished by their more elongate appearance, resulting in a minor axis lacking spines on the basal ring. Dictyocha messanensis of Murray and Schrader (1983) is recognized as Dictyocha stapedia. Similarly, Dictyocha epidon of Murray and Schrader (1983) is recognized as D. aculeata. Large specimens of Dictyocha that have canted apical bar and slightly bowed basal ring, reminiscent of $D$. aculeata, are recorded as $D$. sp. aff. D. aculeata. These probably represent an endemic Gulf variant of $D$. aculeata, which is associated with the modern California Current. Octactis pulchra specimens were separated into three size categories: (1) larger specimens; (2) medium specimens that were typically one half the size of the larger specimens; and (3) small specimens that were typically one-fourth the size of the larger specimens. In addition, Octactis pulchra specimens possessing a relatively thick skeleton were also counted separately.

\subsection{Age model}

Chronology for Core 3 of DSDP 480 is after Keigwin and Jones (1990) updated to calendar yr BP using the CALIB 4.3 program of Stuiver et al. (1998) and a Gulf reservoir correction of $725 \mathrm{yr}$ (Keigwin, 2002). These authors used AMS dating of planktonic foraminifera to confirm that the non-laminated sediments recovered between 10.4 and 11.05 mbsf coincided with the YD.

Numerous unsuccessful efforts were made to obtain AMS dates from Cores 1 and 2 of DSDP 480. Foraminifera are extremely rare in these intervals, so that even the processing of large sample sizes $(>40 \mathrm{cc})$ of sediment failed to yield enough foraminifera $(\sim 3 \mathrm{mg})$ for analysis. Thus, no direct AMS-based age model exists for Cores 1 and 2.

Nearby Kasten core BAM80 E-17, however, is well dated by AMS methods (Murray, 1982) and varve counting (Karlin and Levi, 1985). Murray (1982) used silicoflagellate data to correlate the top of sediment recovered in Core 1 of DSDP

Table 1

Age calibration points for DSDP 480

\begin{tabular}{|c|c|c|}
\hline $\begin{array}{l}\text { Depth } \\
\text { (mbsf) }\end{array}$ & $\begin{array}{l}\text { Age } \\
\left(\mathrm{ka}^{*}\right)\end{array}$ & Basis of age \\
\hline 0 & 1.33 & $\begin{array}{l}\text { Murray (1982) silicoflagellate } \\
\text { correlation w/180 cm level of BAM } 80 \\
\text { E-17 }\end{array}$ \\
\hline 1.4 & 2.7 & $\begin{array}{l}\text { Magnetic secular variation correlation } \\
\text { (Harris and Karlin, written commun., } \\
\text { 2001) }\end{array}$ \\
\hline 2.2 & 3.4 & $\begin{array}{l}\text { Magnetic secular variation correlation } \\
\text { (Harris and Karlin, written commun., } \\
\text { 2001) }\end{array}$ \\
\hline 5.7 & 6.45 & $\begin{array}{l}\text { Magnetic secular variation correlation } \\
\text { (Harris and Karlin, written commun., } \\
\text { 2001) }\end{array}$ \\
\hline 7.0 & 7.6 & $\begin{array}{l}\text { Magnetic secular variation correlation } \\
\text { (Harris and Karlin, written commun., } \\
\text { 2001) }\end{array}$ \\
\hline 7.7 & 8.2 & $\begin{array}{l}\text { Magnetic secular variation correlation } \\
\text { (Harris and Karlin, written commun., } \\
\text { 2001) }\end{array}$ \\
\hline 10.4 & 11.6 & $\begin{array}{l}\text { Top Younger Dryas (Keigwin and } \\
\text { Jones, 1990) }\end{array}$ \\
\hline 10.51 & 11.83 & $\begin{array}{l}\text { AMS calendar age on } N \text {. deuterei } \\
\text { (Keigwin and Jones, 1990) }\end{array}$ \\
\hline 10.81 & 12.34 & $\begin{array}{l}\text { AMS calendar age on } N \text {. deuterei } \\
\text { (Keigwin and Jones, 1990) }\end{array}$ \\
\hline 11.15 & 12.9 & $\begin{array}{l}\text { Base Younger Dryas (Keigwin and } \\
\text { Jones, 1990) }\end{array}$ \\
\hline 13.05 & 14.6 & $\begin{array}{l}\text { Base Bølling-Allerød (Keigwin and } \\
\text { Jones, 1990; Pide et al., 1999) }\end{array}$ \\
\hline 13.11 & 14.73 & $\begin{array}{l}\text { AMS calendar age on } N \text {. deuterei } \\
\text { (Keigwin and Jones, 1990) }\end{array}$ \\
\hline 13.51 & 15.45 & $\begin{array}{l}\text { AMS calendar age on } N \text {. deuterei } \\
\text { (Keigwin and Jones, 1990) }\end{array}$ \\
\hline
\end{tabular}




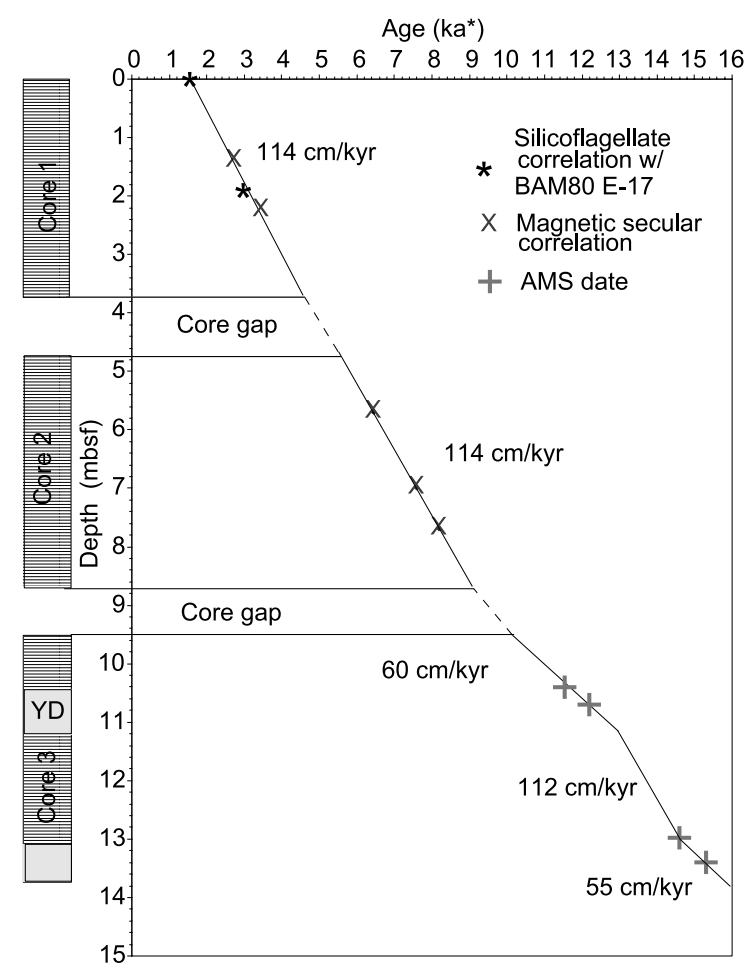

Fig. 3. Age model used for Cores 1-3 of DSDP 480. Laminated sediments indicated by horizontal bar pattern, massive sediments indicated by stipple pattern. Abbreviations: mbsf, meters below seafloor; $\mathrm{ka}^{*}=1000 \mathrm{cal}$ yr BP.

480 with the $180-\mathrm{cm}$ horizon of BAM80E-17. Acceptance of Karlin and Levi's (1985) sedimentation rate of $135 \mathrm{~cm} / \mathrm{kyr}$ for BAM80 E-17, would imply that the youngest sediment recovered in Core 1 of DSDP 480 would thus be $\sim 1.33 \mathrm{ka}$ in age.

Ann Marie Harris and Robert Karlin provide a detailed correlation of the magnetic secular variation record of ODP 1033 in the Saanich Inlet with the inclination record of DSDP Site 480 that allows absolute ages to be assigned to parts of Cores 1 and 2 (Harris and Karlin, in prep. (written commun., 2001)). This correlation utilizes the results of Verosub et al. (2001), which demonstrated that the sediments of Saanich Inlet ODP Site 1033 represent a reliable record of geomagnetic field behavior that is well dated by radiocarbon.

Fig. 3 shows the age model adopted for Cores 1-3 of DSDP 480 based on the age calibrations of
Table 1. Core gaps, intervals of unrecovered sediments, lying between Cores 1 and 2 (3.80-4.75 mbsf) and between Cores 2 and 3 (8.89-9.50 mbsf) are projected as non-recovered time intervals. The suggested sediment accumulation rate of $114 \mathrm{~cm} / \mathrm{kyr}$ for Cores 1 and 2 agrees precisely with the value estimated by Keigwin and Jones (1990) for this interval. Anne-Marie Harris' (written commun., 2001) varve counts for Cores 1 and 2 of DSDP 480 consistently range between $\sim 100$ and $130 \mathrm{~cm} / \mathrm{kyr}$ (written commun., 2001), in further agreement.

\section{Results}

\subsection{Geochemistry}

Results of bulk ICP-AES geochemical analyses and coulometry on DSDP 480 samples between $\sim 15.2$ and $1.3 \mathrm{ka}$ are presented in Table 2 with ages calculated according to the age model of Fig. 3. The lack of available downcore density data at DSDP 480 (Shipboard Scientific Party, 1982) prevents the determination of mass accumulation rates.

\subsubsection{Biogenic proxies}

$\mathrm{Wt} \% \mathrm{CaCO}_{3}$ biogenic silica, and total organic carbon are compared with a plot of $\mathrm{Ba} / \mathrm{Al}$ ratios for the past 15000 years at DSDP 480 on Fig. 4. Maximum $\mathrm{CaCO}_{3}(15-20 \%)$ occurs during the late Glacial (15.0-14.6 ka) and YD (12.9-11.6 ka) with minimal values $(>4 \%)$ coinciding with the Bølling-Allerød (14.6-12.9 ka) and the Holocene $(9.0-1.3 \mathrm{ka})$. Intermediate $\mathrm{CaCO}_{3}(3-7 \%)$ characterizes the earliest Holocene period between ca. 11.6 and $10.0 \mathrm{ka}$.

The record of biogenic silica shows a mostly inverse correlation with that of $\mathrm{CaCO}_{3}$. Very near the base of the Bølling-Allerød, biogenic silica abruptly increases from late Glacial values averaging $\sim 7 \%$ to Bølling-Allerød values averaging $\sim 25 \%$. At the base of the YD, on the other hand, biogenic silica abruptly falls to late Glacial values $(\sim 6 \%)$.

The Holocene record of biogenic silica at DSDP 480 shows stepwise increases at $\sim 11.4$ 
ka, $8.2 \mathrm{ka}$, and $6.2 \mathrm{ka}$ (Fig. 4). At $11.4 \mathrm{ka}$ biogenic silica increases from average YD values of $\sim 5 \%$ to $\sim 15 \%$. Thereafter, a gradual rise to $\sim 20 \%$ occurs until $\sim 8.3 \mathrm{ka}$, followed by an abrupt increase to $\sim 36 \%$ at about $8.2 \mathrm{ka}$. This $8.2 \mathrm{ka}$ increase, however, was apparently shortlived, as biogenic silica values dropped after $\sim 8.0 \mathrm{ka}$ to values ranging between $\sim 15$ and $26 \%$ until $\sim 6.2$ ka. After $\sim 6.2 \mathrm{ka}$, biogenic silica typically ranges between 25 and $35 \%$ at DSDP 480, with peak values gradually increasing after $\sim 2.4 \mathrm{ka}$ (Fig. 4).

The ratios of organic carbon to $\mathrm{Al}$ (C-org/Al) and the $\mathrm{Ba} / \mathrm{Al}$ are commonly used as proxies for paleoproductivity (Dean et al., 1997; Kienast et al., 2002). Aside from a peak in $\mathrm{Ba} / \mathrm{Al}$ at $\sim 11.4$ $\mathrm{ka}, \mathrm{Ba} / \mathrm{Al}$ values are relatively low prior to $9 \mathrm{ka}$ compared to those afterward, and especially after $6.2 \mathrm{ka}$ (Fig. 4). A $50 \%$ increase in $\mathrm{Ba} / \mathrm{Al}$ between $\sim 6.6$ and $6.2 \mathrm{ka}$ stands out as the most remarkable feature of the $\mathrm{Ba} / \mathrm{Al}$ record. This increase parallels a major increase in biogenic silica at $6.2 \mathrm{ka}$. Since the method used to calculate biogenic silica is dependent on terrigenous components such as $\mathrm{Al}$, this result is not surprising. However, as the $\mathrm{Ba} / \mathrm{Al}$ ratio begins to increase at least $0.2 \mathrm{kyr}$ before the biogenic silica does, the $\mathrm{Ba} / \mathrm{Al}$ increase probably also reflects an increase in biogenic Ba. Clearly, a major change in oceanographic conditions occurred in the Gulf at $\sim 6.2$ $\mathrm{ka}$ that resulted in increased biogenic productivity and diatom deposition in the eastern Guaymas Basin.

Table 2

Results of ICP-AES geochemical and coulometric analyses at DSDP 480 (see Section 2)

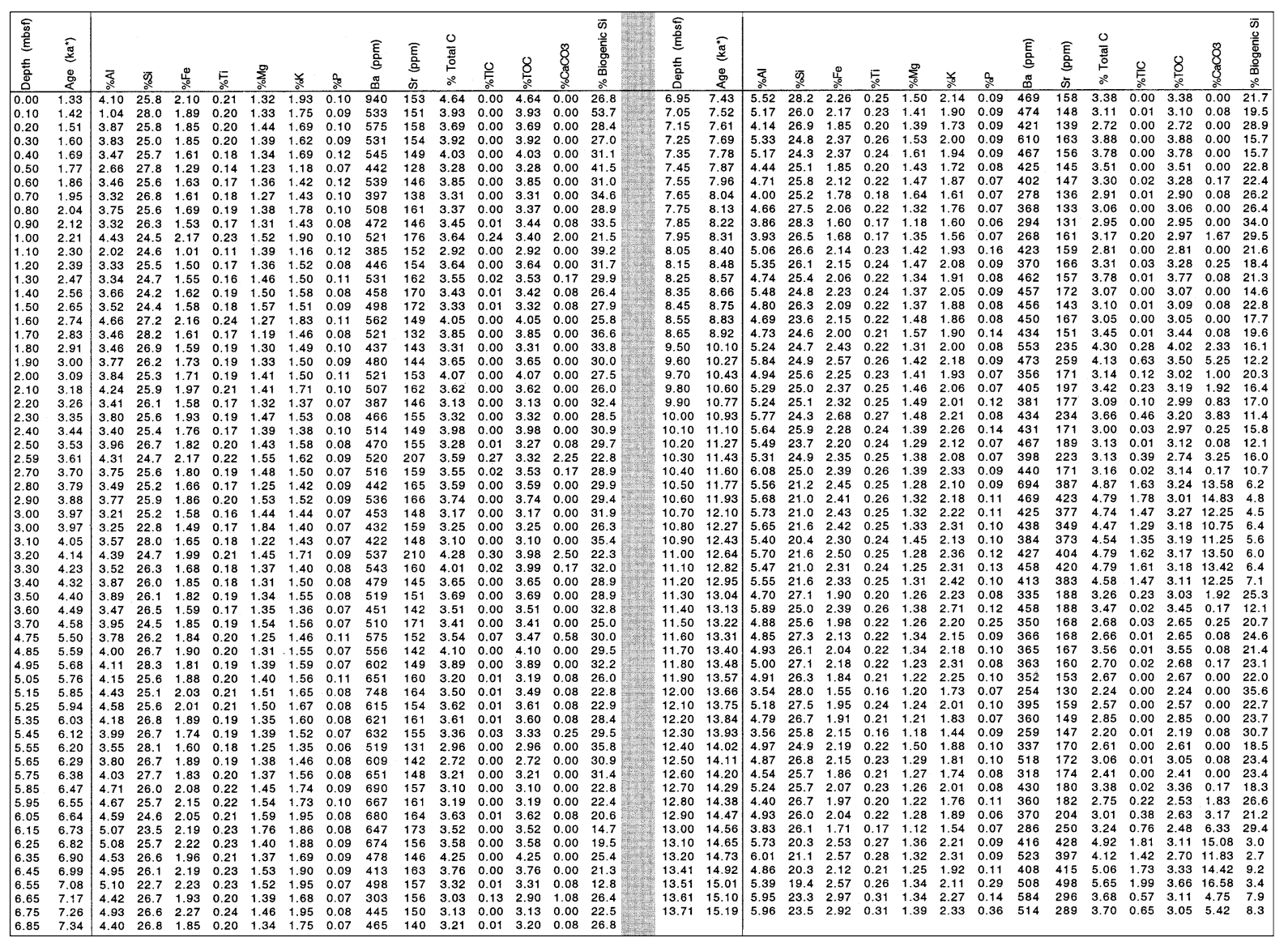

Mbsf $=$ meters below sea floor; $\mathrm{ka}^{*}=1000 \mathrm{cal}$ yr B.P. 

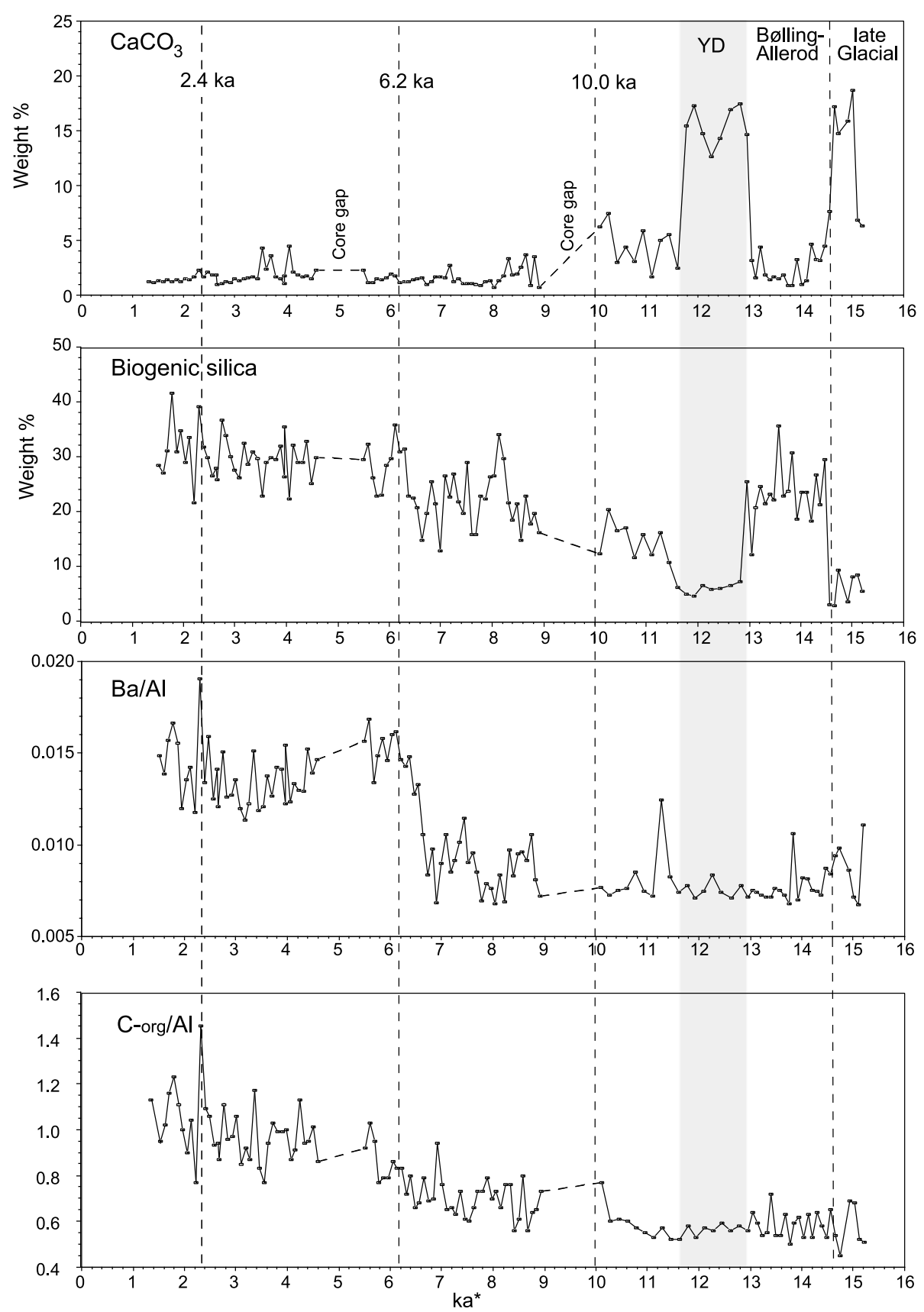

Fig. 4. Comparison of proxy records of biogenic productivity - calcium carbonate, biogenic silica, $\mathrm{Ba} / \mathrm{Al}$, and $\mathrm{C}$-org/Al - at DSDP 480. ka* refers to 1000 cal yr BP. Core gaps are shown.

The C-org/Al curve displays stepwise increases at $\sim 10.0,5.6$ and $2.4 \mathrm{ka}$, similar to the general trends of the biogenic silica and $\mathrm{Ba} / \mathrm{Al}$ curves (Fig. 4). All three curves display increased ampli- tude variations after $\sim 10 \mathrm{ka}$, coinciding with the decline of calcium carbonate and the increasing importance of diatoms in the eastern Guaymas Basin. 


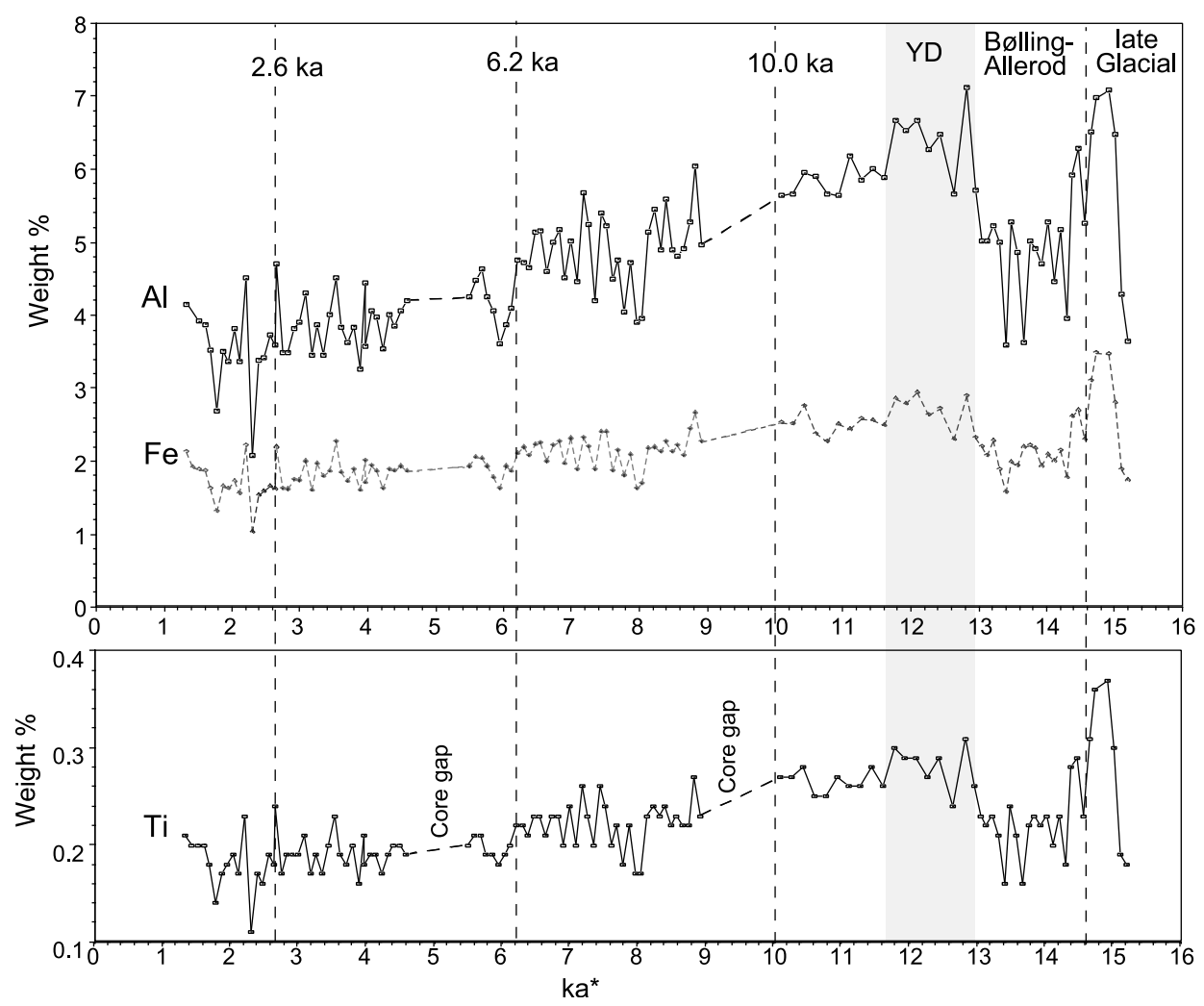

Fig. 5. Comparison of the terrigenous proxy record at DSDP Site 480. ka* refers to $1000 \mathrm{cal}$ yr BP. Core gaps are shown.

\subsubsection{Terrigenous proxies}

$\mathrm{Wt} \% \mathrm{Al}, \mathrm{Fe}$, and $\mathrm{Ti}$ (Fig. 5) are taken as proxies for terrigenous deposition given the largely two-component character (biogenic silica and terrigenous debris) of Guaymas Basin sediments (Baba et al., 1991). This terrigenous material probably reflects input from rivers which peaks during the summer-fall from the Sonoran (eastern) side of the Gulf. Alternatively, as Baumgartner et al. (1991) argue, transfer of terrigenous material in the modern central Gulf occurs mainly through eolian processes by removal and transport of desert dust associated with convective summer thunder storms.

Fig. 5 shows remarkably parallel upsection trends of decreasing $\mathrm{wt} \% \mathrm{Al}, \mathrm{Fe}$, and $\mathrm{Ti}$ beginning with the YD and continuing through the Holocene. Steps in this trend occur at $\sim 10.0 \mathrm{ka}$ and $6.2 \mathrm{ka}$, with an increase in amplitude of the values at $\sim 2.6 \mathrm{ka}$. These stepwise decreases in the terrigenous proxies closely match increases in the biogenic silica (Fig. 4), further emphasizing the two-component nature of the DSDP 480 record after $\sim 10.0 \mathrm{ka}$. At the same time, the upsection decrease in terrigenous content suggested by the $\mathrm{Al}$, Ti and Fe data may reflect, in part, the rise in sea level in the narrow Gulf and a progressive eastward shift in the shoreline further and further from Site 480.

\subsection{Diatoms}

The relative percentages of diatoms in the DSDP 480 record between 15.2 and $1.3 \mathrm{ka}$ is tabulated on Table 3 along with ages calculated according to the age model of Fig. 3. Fig. 6 compares the changes in the relative percentages of the important planktonic diatoms Azpeitia nodulifera, Coscinodiscus spp., and Roperia tesselata in the DSDP 480 record.

According to Sancetta (1995), Azpeitia nodulifera, a tropical diatom whose presence in the 
modern Gulf is associated with El Niño-like conditions, is most common (typically $50-60 \%$ ) during the latest glacial (15.2-14.6 ka) and YD (12.9$11.6 \mathrm{ka})$ and moderately common during the Bølling-Allerød ( 30\%) (14.6-12.9 ka). During the earliest Holocene between 11.6 and $10.6 \mathrm{ka}$, A. nodulifera makes up $10-20 \%$ of the counted assemblage, whereas between 10.6 and $6.2 \mathrm{ka}$ it is essentially absent from DSDP 480 sediments, a result also found by Sancetta (1995) in JPC-56 in the western Guaymas Basin. After $6.2 \mathrm{ka}, A$. nodulifera varies between $\sim 2 \%$ and $30 \%$ of the DSDP 480 diatom assemblage.

Coscinodiscus spp. include C. asteromphalus,
C. granii, and C. oculus-iridis, large-diameter taxa that are associated with stratified, low nutrient waters of the summer-early fall, but are deposited in the late fall (the 'fall dump' of Kemp et al., 2000) when the thermocline breaks down after the onset of northwest winds. Unfortunately, C. radiatus, a species more common in the mixed waters of the winter, was not differentiated from other Coscinodiscus species in these counts, thereby limiting the application of these data to paleoenvironmental interpretation.

Coscinodiscus spp. typically vary between $10 \%$ and $30 \%$ of the tabulated diatom assemblage of DSDP 480 between 15.2 and $1.3 \mathrm{ka}$, apparently

Table 3

Relative abundance of key diatom taxa in samples studied from DSDP 480 (Section 2)

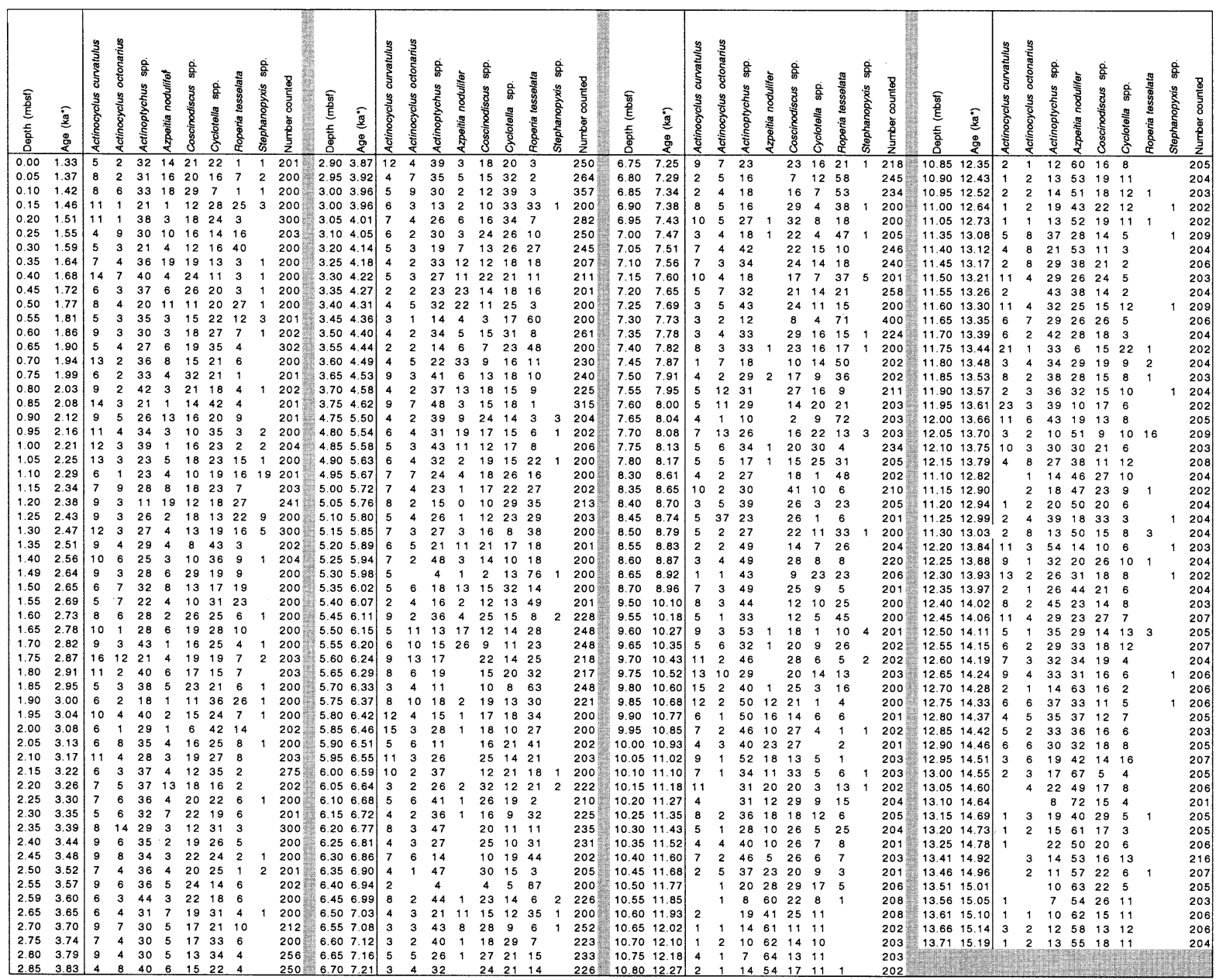



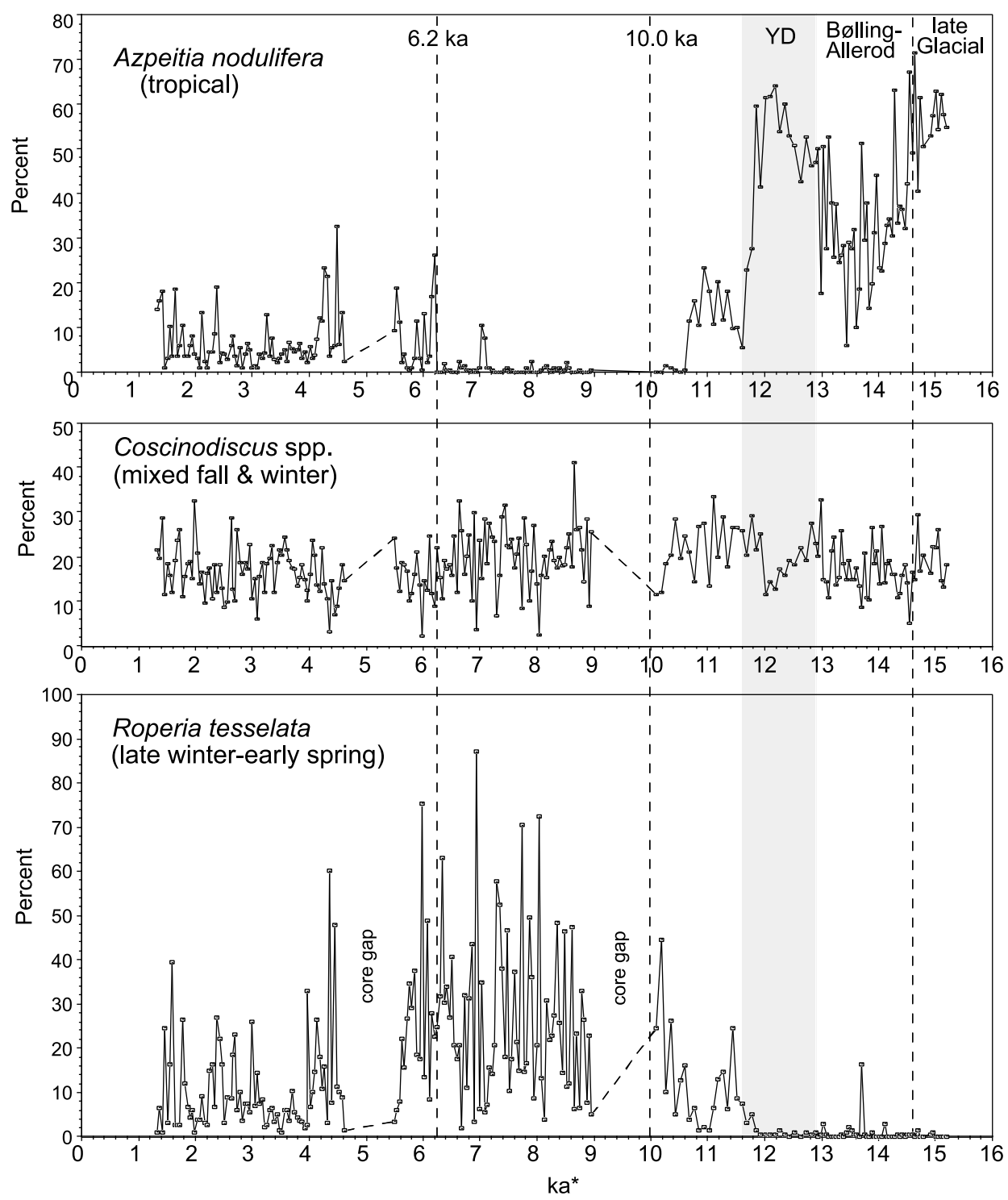

Fig. 6. Comparison of the relative contributions of important diatom taxa during the past $15.2 \mathrm{kyr}$ at DSDP 480. Percentage values are from counts of selected taxa (see Section 2). ka* refers to 1000 cal yr BP. Core gaps are shown.

without the long term abundance variations shown by $A$. nodulifera. Cycles of changing relative abundance of Coscinodiscus spp. occur almost every other sample throughout the record, although the amplitude of these variations appears to be greatest between $\sim 9$ and $6 \mathrm{ka}$.

Roperia tesselata is thought by Sancetta (1995) to be a late winter-early spring diatom indicative of waters that are well mixed by northwest winds.
Schrader et al. (1986) noted that $R$. tesselata dominated their June of 1982 phytoplankton stations in the northern Gulf (north of $28^{\circ} 30^{\prime} \mathrm{N}$ ) (SSTs $<20^{\circ} \mathrm{C}$ ), implying that it is associated with the cooler waters of the northern Gulf. This diatom species is virtually absent from the late Glacial, Bølling-Allerød, and YD intervals of DSDP 480. During the earliest Holocene, it quickly rises to $10-20 \%$ of the assemblage between 11.4 and 


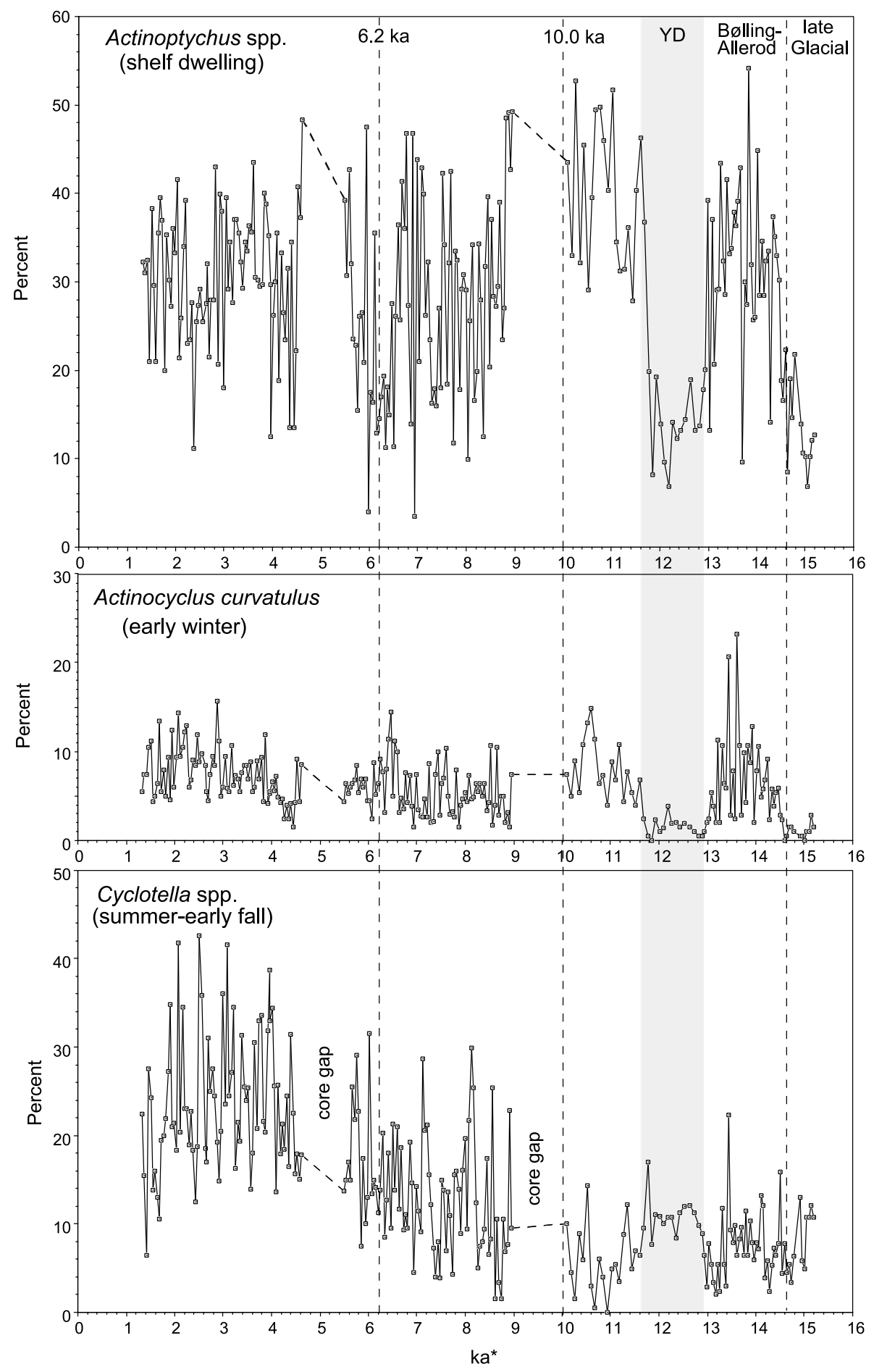

Fig. 7. Comparison of the relative contributions of key diatom taxa during the past $15.2 \mathrm{kyr}$ at DSDP 480. Percentage values are from counts of selected taxa (see Section 2). ka* refers to $1000 \mathrm{cal}$ yr BP. Core gaps are shown. 
$11.2 \mathrm{ka}$, falls briefly below $5 \%$ between 11.0 and $10.8 \mathrm{ka}$, and thereafter begins a steady rise to peak values that are as much as $40 \%$ of the assemblage by $10.2 \mathrm{ka}$.

The middle part of the Holocene between $\sim 10$ and $4.5 \mathrm{ka}$ is marked by peak relative abundances of Roperia tesselata $>40 \%$, alternating in rapid succession $(\sim 50-100 \mathrm{yr})$ with intervals of reduced $(<20 \%)$ relative abundance. During this interval, these cycles are negatively correlated with those of Coscinodiscus spp. $\left(r^{2}=0.507\right)$. It is possible that these cycles reflect preservation, as valves of $R o$ peria tesselata tend to be more finely silicified that those of Coscinodiscus. On the other hand, they may have climatic significance, as higher values of $R$. tesselata coincide with a shallower thermocline (= more mixing by winter winds), whereas higher values of Coscinodiscus spp. (particularly the large diameter forms) indicate a deeper thermocline (less mixing by winds). Whatever the cause, the negative correlation of Roperia tesselata and Coscinodiscus spp. is reduced after $\sim 4 \mathrm{ka}\left(r^{2}=0.295\right)$.

The relative percentage changes of Actinoptychus spp., Actinocyclus curvatulus, and Cyclotella spp. between $\sim 15.2$ and $1.3 \mathrm{ka}$ in DSDP 480 are shown in Fig. 7. Sancetta (1995) regards Actinoptychus spp. as shelf dwelling forms that are advected down the slope by summer storms and/or by periods of lower sea level. In this regard, the major drop in relative percentage of Actinoptychus spp. after $\sim 8.8 \mathrm{ka}$ may be due to rising sea level. Reduced numbers during the YD $(<20 \%)$ likely reflect both reduced diatom production and poorer preservation.

Actinocyclus curvatulus is an early winter taxon indicative of upwelling mixed waters according to Sancetta (1995). The DSDP 480 record of $A$. curvatulus typically displays relative percentage fluctuations between $\sim 5$ and $15 \%$ of the diatom assemblage. An exception is found during the YD, where values do not exceed $3 \%$, possibly reflecting reduced diatom productivity and poorer preservation then. Actinocyclus curvatulus is relatively more finely silicified than Azpeitia nodulifera, Coscinodiscus radiatus, and Roperia tesselata, so it is possible that the fluctuations in its relative abundance reflect changing preservation.

Cyclotella spp (mainly $C$. littoralis) is a coastal taxon indicative of low production in warm, stratified, and nutrient-limited waters of the summer and early fall according to Sancetta (1995). High amplitude cycles in the relative abundance of Cyclotella spp. characterize the DSDP 480 record after $\sim 9 \mathrm{ka}$. During the Bølling-Allerød, YD, and early Holocene, Cyclotella spp. typically make up $10 \%$ of the diatom assemblage, but between $\sim 9$ and 4 ka peak values rise to 20 to $30 \%$ of the diatom assemblage during a period of increasing biogenic silica production (Fig. 4). Sancetta (1995) records a similar middle Holocene increase in her Cyclotella-dominated Summer/Fall factor in western Guaymas Basin core JPC-56, but she cautions that this increase might reflect better preservation of the relatively weakly silicified valves of Cyclotella spp. Peak values of $C y$ clotella spp. rise to $35-40 \%$ of the diatom assemblage between $\sim 4$ and 2 ka (Fig. 7), before falling below $\sim 30 \%$ after $2 \mathrm{ka}$.

\subsection{Silicoflagellates}

The relative percentages of silicoflagellate taxa in the DSDP 480 record between 15.2 and $1.3 \mathrm{ka}$ is tabulated in Table 4 along with ages calculated according to the age model of Fig. 3.

Fig. 8 plots the relative percentages of four forms of Octactis pulchra, a silicoflagellate tied to high productivity in the Gulf by Murray and Schrader (1983) and Dictyocha stapedia, a cosmopolitan taxon. Octactis pulchra is more common ( $>60 \%$ of the silicoflagellate assemblage) during the Bølling-Allerød (14.6-12.9 ka) and during the late Holocene after $\sim 2.8 \mathrm{ka}$. The small and medium forms of $O$. pulchra are typically the most common forms recorded, with the large and thick forms only having minor representation. It was argued by Barron et al. (2003a) that the small form of $O$. pulchra would be more likely to be preserved in periods of increased silicoflagellate flux or higher productivity. Fig. 8 reveals that when small forms of $O$. pulchra are most common ( $>50 \%$ of the silicoflagellate assemblage), other forms of $O$. pulchra are reduced in their relative abundance (i.e. at $\sim 13.6-13.2 \mathrm{ka}, 4.5 \mathrm{ka}, 2.6 \mathrm{ka}$, and $2.2 \mathrm{ka}$ ), possibly signaling increased silicoflagellate productivity. 
Dictyocha stapedia is most common ( $>50 \%$ of the assemblage) during most of the early and middle Holocene interval between $\sim 11.4$ to $3.2 \mathrm{ka}$ where Octactis pulchra is reduced in its abundance. This interval of increased D. stapedia is similar to the $\sim 10.2$ to $4.5 \mathrm{ka}$ interval of increased Roperia tesselata seen in diatoms (Fig. 6), and is further evidence of anomalous conditions in the Gulf during these times. The association of both $R$. tesselata and D. stapedia (as D. messanensis) with the cooler waters of the northern Gulf (north of $28^{\circ} 30^{\prime} \mathrm{N}$ ) by Schrader et al. (1986) would seem to suggest that during this early and middle Holocene period the waters above DSDP 480 were cooler and slightly more saline than they are at present.

At $\sim 3.2 \mathrm{ka}$, Octactis pulchra returns to dominance over Dictyocha stapedia. In BAM80 E-17, Murray (1982) records this D. stapedia-O. pulchra crossover at a depth of $\sim 400 \mathrm{~cm}$, which has an interpolated age of $\sim 3.0 \mathrm{ka}$ according to Karlin and Levi's (1985) age model. This silicoflagellate event, therefore, suggests that the age model used for Core 1 of DSDP 480 is at most $200 \mathrm{yr}$ off (Fig. 3).

In Fig. 9, the relative abundance of the tropical silicoflagellates, Dictyocha, including D. calida, D. calida ampliata and D. perlaevis, are compared

Table 4

Relative abundance of silicoflagellate taxa in samples studied from DSDP 480

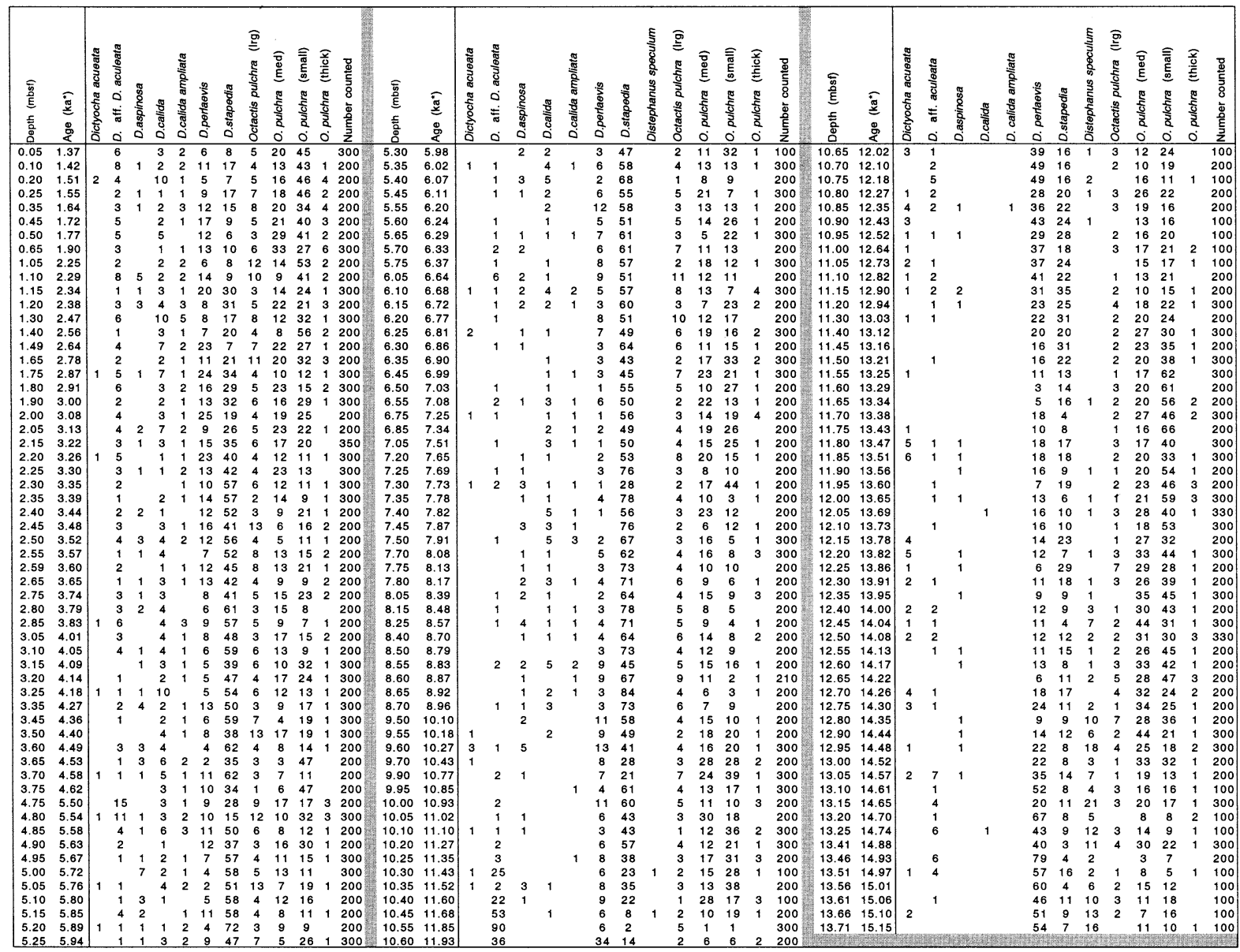

See Table 3 for sample identification. 

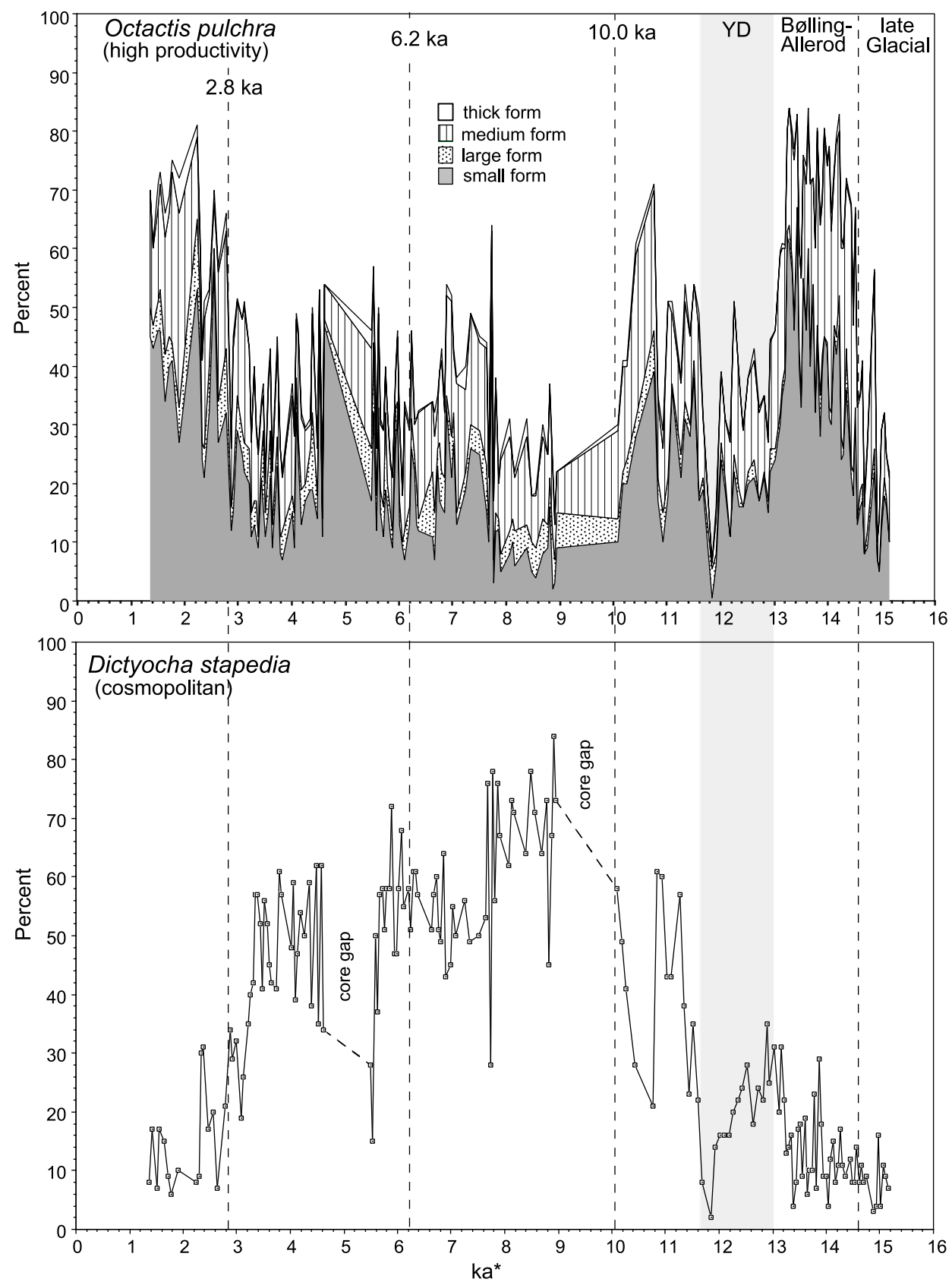

Fig. 8. Comparison of the relative contributions of important silicoflagellate taxa during the past $15.2 \mathrm{kyr}$ at DSDP 480 . ka* refers to $1000 \mathrm{cal}$ yr BP. Core gaps are shown.

with those of $D$. aculeata and the related taxon $D$. sp. aff. D. aculeata. The distribution of tropical Dictyocha species (mainly D. perlaevis) is similar to that of the tropical diatom Azpeitia nodulifera
(Fig. 6), i.e. high prior to $14.6 \mathrm{ka}$, reduced in the Bølling-Allerød, high again in the YD, and reduced, but variable, throughout much of the Holocene. Relative abundance cycles of $D$. perlaevis 

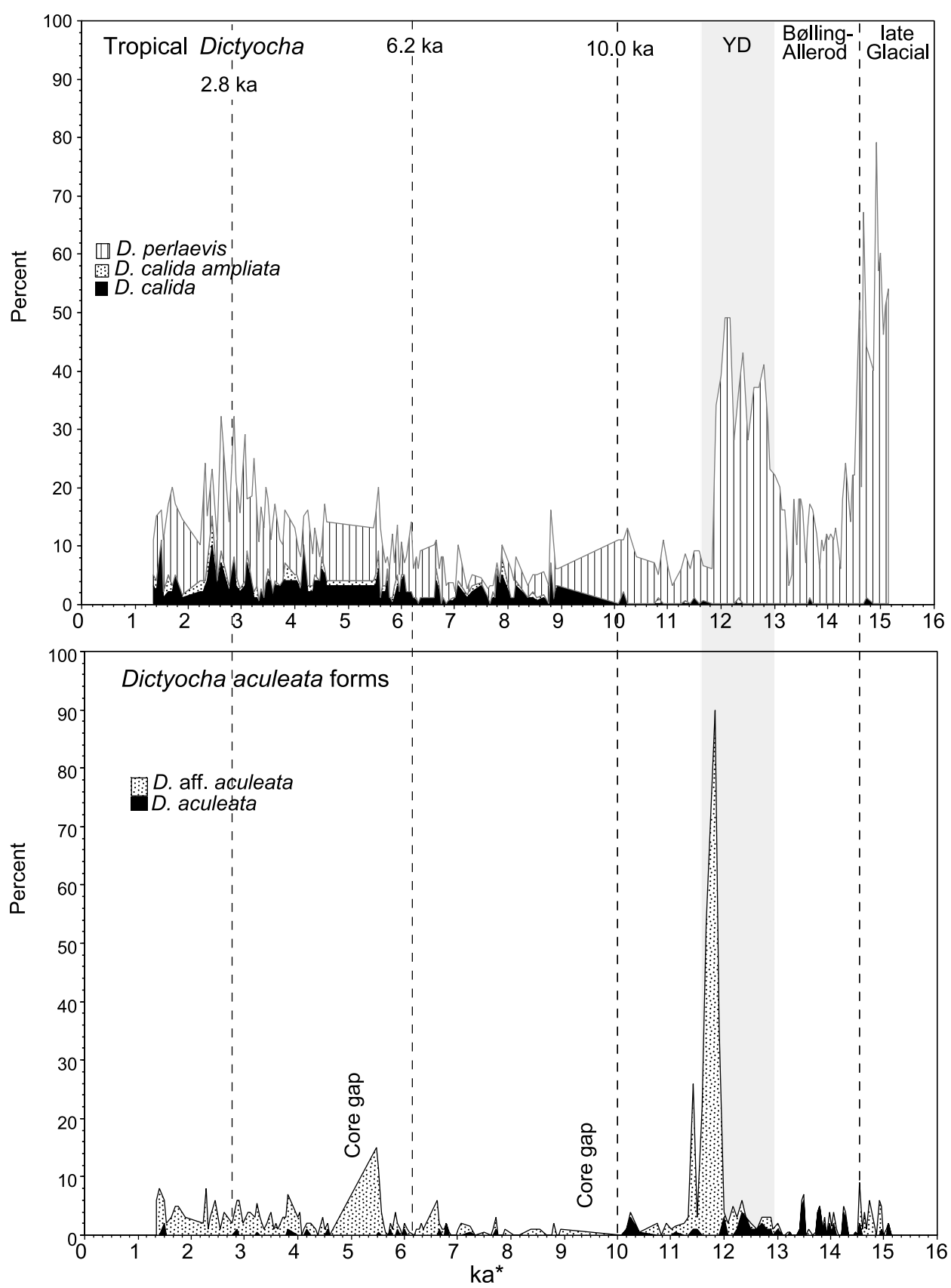

Fig. 9. Comparison of the relative contributions of important Dictyocha taxa during the past 15.2 kyr at DSDP 480 . ka* refers to $1000 \mathrm{cal}$ yr BP. Core gaps are shown.

increase in amplitude between $\sim 3.2$ and $2.3 \mathrm{ka}$, possibly suggesting periodically increased incursions of subtropical waters into the Gulf (increased El Niño cycles?).
Dictyocha aculeata, a taxon associated with the modern California Current, is sporadic and very rare $(<5 \%)$ throughout the DSDP 480 record. On the other hand, Dictyocha sp. aff. D. aculeata, 
a Gulf variant distinguished by its larger size and canted apical bar as well as slightly bowed basal ring, increases to $>50 \%$ of the silicoflagellate assemblage during a very brief period near the end of the YD $(\sim 11.8-11.6 \mathrm{ka})$. Fig. 9 reveals that Dictyocha sp. aff. D. aculeata becomes a more consistent, but rare, member of Gulf assemblages during the late Holocene. High resolution studies of the past $2000 \mathrm{yr}$ at nearby BAM $80 \mathrm{E}-17$ reveal that this taxon makes up more than $15 \%$ of silicoflagellate assemblages only during two intervals, the period identified as the Medieval Warm Period (AD 910-1140) and the past 200 years. It was argued by Barron et al. (2003a) that increased Dictyocha sp. aff. D. aculeata was indicative of anomalously warm conditions of reduced diatom and silicoflagellate production.

\section{Discussion}

\subsection{Intermediate waters}

As noted by Keigwin and Jones (1990), Pride et al. (1999) and Keigwin (2002), cores in the Guaymas Basin in the depth range of $500-900 \mathrm{~m}$ are characterized by non-laminated sediments deposited during the last glacial maximum and YD intervals, and finely laminated Bølling-Allerød and Holocene sediments. Correspondence of bioturbated (massive sediments) with the last glacial and the YD interval reveals that the intermediate waters in the central Gulf were better ventilated with oxygen at these times, allowing the development of a burrowing infauna on the seafloor. Keigwin (2002), however, argued that 'neither benthic $\delta^{13} \mathrm{C}$ in depth section nor paired benthic and planktonic ${ }^{14} \mathrm{C}$ data in JPC56 are consistent with increased intermediate water ventilation during the glacial maximum and Younger Dryas'.

\subsection{Bølling-Allerød (14.6-12.9 ka)}

During the Bølling-Allerød interval, marine conditions in the central Gulf were apparently similar to those of today, with high winter upwelling produced by northwest winds (Sancetta, 1995; Pride et al., 1999). At the beginning of the
Bølling-Allerød, wt $\%$ biogenic silica abruptly increased more than fourfold at DSDP 480, an event also documented by Pride et al. (1999) in JPC-56 in the western Guaymas Basin. At the same time, $\mathrm{CaCO}_{3}$ abruptly declined more than fivefold, while terrigenous proxies ( $\mathrm{Al}, \mathrm{Fe}$, and Ti) also declined. Silicoflagellate assemblages resembled those of the modern Gulf with increased Octactis pulchra, the productivity indicator, and decreased tropical Dictyocha spp. compared to the immediately preceding late Glacial period. Similar to the findings of Sancetta (1995) in JPC-56, reduced numbers of Roperia tesselata and Cyclotella spp. and enhanced numbers of $A z$ peitia nodulifera in diatom assemblages of DSDP 480 suggest that summer (monsoon) conditions were more dominant over winter (wind-driven upwelling) conditions during the Bølling-Allerød than they are in the modern Guaymas Basin.

\subsection{Younger Dryas (12.9-11.6 ka)}

At DSDP Site 480 , the YD is marked by reduced biogenic silica and reduced numbers of diatoms and silicoflagellates that are associated with winter-spring upwelling (Roperia tesselata, Octactis pulchra). This argues for a reduction in winterspring NW winds and/or reduction in the nutrient content of the upwelled waters during the YD, conclusions that are supported by the studies of Sancetta (1995) and by Pride et al. (1999) of JPC56. Increased $\mathrm{CaCO}_{3}$ and tropical diatoms and silicoflagellates seem to suggest that tropical conditions may have persisted over a greater portion of the year in the Gulf. However, a packrat midden record with a calibrated age range of about 12.4-11.5 ka from central Baja California contains remains of California juniper, suggesting to Rhode (2002) a climate that was $5-6^{\circ} \mathrm{C}$ cooler than that of today with at least twice the winter precipitation. Such an interpretation of cooler conditions during the YD is consistent with results in the Santa Barbara Basin (Kennett and Ingram, 1995) and off the coast of northern California (Mix et al., 1999; Barron et al., 2003b); however, Keigwin (2002) did not record significant changes in $\delta^{18} \mathrm{O}$ in either benthic or planktonic foraminifera at JPC-56. The apparent 
warmer character of the diatom and silicoflagellate assemblages during the YD at DSDP 480 is likely the result of reduced upwelling of nutrientrich waters and a marked decline in the winterspring, upwelling assemblages.

\subsection{Earliest Holocene (11.6-10.0 ka)}

The end of the YD is marked by an abrupt return to laminated sediments at DSDP 480 and at JPC-56 (Keigwin and Jones, 1990; Sancetta, 1995; Pride et al., 1999). Biogenic silica and the relative percentages of Octactis pulchra rapidly recover in the earliest part of the Holocene to about half the values of the highs of the Bølling-Allerød. Calcium carbonate percentage is moderately high (roughly $5 \%$ ) compared that of the Bølling-Allerød or Holocene.

Terrigenous proxies start a decreasing trend after the YD which persists throughout most of the Holocene (Fig. 5). This trend may reflect decreasing terrigenous input during the Holocene due to increasing aridity on the mainland, a trend that is generally supported by the climate record from northwest Mexico (Metcalfe et al., 2000). Alternatively, this trend may be due to increasing dilution by biogenic silica (Fig. 4).

Van Devender et al. (1990) propose that the early Holocene climate of the Sonoran Dessert, northwest of the Gulf, was characterized by more winter precipitation than at present, but was marked by only a small increase in summer, monsoonal rainfall compared with glacial conditions. They argue that the modern rainfall patterns with a dry winter dominated by northwest winds and a wet, monsoonal summer was established about $9 \mathrm{ka}$. Support comes from the atmospheric modeling study of Bartlein et al. (1998), which reveals that prior to $\sim 10 \mathrm{ka}$, winter winds along the NW coasts of Mexico were predominantly from the southeast or monsoonal (and more moisture laden) in character.

\subsection{Early to middle part of the Holocene $(10.0-6.2 \mathrm{ka})$}

The disappearance of the tropical diatom $\mathrm{Az}$ peitia nodulifera from sediments of the Guaymas
Basin at $\sim 10.6 \mathrm{ka}$ (Sancetta, 1995; this study, Fig. 6) and the permanent decline in $\mathrm{wt} \% \mathrm{CaCO}_{3}$ after $10 \mathrm{ka}$ (Fig. 4) may be reflective of cessation of these wintertime southeasterly winds. Marked increases in the relative percentage contribution of Roperia tesselata after $\sim 10.2$ ka (Fig. 6) attest to intensification of the northwest winds during the winter. At the same time, between $\sim 10.2$ and 3.2 ka, Dictyocha stapedia, a cosmopolitan silicoflagellate that is today more common in the cooler waters of the northern Gulf (Schrader et al., 1986), dominates DSDP 480 assemblages. It would appear that cooler and slightly more saline waters similar to those of the modern northern Gulf were present above DSDP 480 during much of the early and middle Holocene period between $\sim 10.2$ and $3.2 \mathrm{ka}$.

\subsection{The 8.2-ka cold event}

The distinctive rise in $\mathrm{wt} \%$ biogenic silica at $\sim 8.2 \mathrm{ka}$ coincides with a permanent decline in wt $\% \mathrm{CaCO}_{3}$ (Fig. 4) and seemingly with a $\sim+0.25 \%$ rise in the oxygen isotopes of benthic foraminifera recorded by Keigwin and Jones (1990) between 8.145 and $7.95 \mathrm{mbsf}$ in DSDP 480.

Global expression of the major 8.2-ka cold event, that is recognized in the GISP-2 Greenland ice core record, is thought to have been due to reduction in the formation of North Atlantic Deep Water caused by the catastrophic release of a massive amount of freshwater from the outburst drainage of North American glacial lakes into the Labrador Sea (Alley et al., 1997; Barber et al., 1999). However, Dean et al. (2002), argue that the 8.2-ka cold event represents a fundamental change in atmospheric circulation over North America based on their study of the Elk Lake record in Minnesota and other climatic records of the western interior of North America. Dean et al. (2002) suggest that a northward shift in the polar front over North America at $\sim 8.2 \mathrm{ka}$ resulted in enhanced westerly flow over the northern Great Plains, resulting in increased aridity there. Barron et al. (2003b) argue that cooling of SSTs and a permanent decline in $\mathrm{CaCO}_{3}$ at $\sim 8.2 \mathrm{ka}$ at ODP Site 1019 of northern California is further evidence of a widespread atmospheric expression 
of the 8.2-ka cold event in western North America. A shift in atmospheric circulation resulting in a winter intensification of northwest winds over the northern Gulf could have resulted in increased diatom production at DSDP 480. Peaks in relative abundance of Roperia tesselata rise from $\sim 50 \%$ to $\sim 70 \%$ at $8.2 \mathrm{ka}$ (Fig. 6), and Octactis pulchra, the productivity-indicator silicoflagellate, undergoes a $\sim 50 \%$ increase in relative abundance shortly afterward (Fig. 8). Pride et al. (1999), however, do not record an increase in opal production in the western Guaymas Basin at this time, so it is likely that coastal upwelling, which is stronger on the mainland side of the Gulf, was more strongly affected by any change in atmospheric circulation associated with the 8.2-ka cold event.

\subsection{Paleoceanographic change at $6.2 \mathrm{ka}$}

Azpeitia nodulifera, an indicator of El Niño conditions in the modern-day Gulf of California, abruptly reappeared in DSDP 480 at $\sim 6.2 \mathrm{ka}$. A strengthening of the present-day Autumn circulation pattern, a relatively weak California Current, a periodically strong North Equatorial Countercurrent and the development of the Costa Rica Current extending northward to the entrance to the Gulf (Baumgartner and Christensen, 1985), may have occurred at this time due to increasing autumn isolation.

A major stepwise increase in biogenic silica and $\mathrm{Ba} / \mathrm{Al}$ also occurs at $\sim 6.2 \mathrm{ka}$, possibly signaling persistence of summer conditions (deep thermocline) into the late fall and deposition (via the 'Fall dump') of large-sized Coscinodiscus spp., which are linked with the maximum opal flux in the modern Gulf (Thunell et al., 1994; Kemp et al., 2000).

On the other hand, in the western part of the Guaymas Basin, Pride et al. (1999) show that a major, permanent increase in $\mathrm{wt} \%$ opal began at $\sim 6 \mathrm{ka}$ in core JPC-56. These east-west differences in opal production may indicate that the mean direction of late winter/early spring winds in the central Gulf shifted to a more northwesterly direction thereby favoring coastal upwelling on the mainland side of the Gulf and reducing it in the western Guaymas Basin. An abrupt increase in the abundance of diatoms at $\sim 6.2 \mathrm{ka}$ in gravity core OXMZ01MV-GC-31 off southern Baja (Fig. 2) (Barron, unpublished data) is additional evidence for such a wind shift. Using a regional climate model for the area between $26.37^{\circ}$ and $47.74^{\circ} \mathrm{N}$ and $136.25^{\circ}$ and $106.20^{\circ} \mathrm{W}$. Diffenbaugh and Sloan (in press) have recently demonstrated that surface wind vectors during February in the northern Gulf were more from a northerly direction during the middle Holocene compared with their modern, more northwesterly, down-the-gulf direction.

In the modern Gulf, upwelling is better developed and extends for a greater distance along the mainland coast than off the Baja California coast (Santamaria-del-Angel et al., 1994; Soto-Mardones et al., 1999). Ziveri and Thunell (2000) note that coccolith accumulation rates are higher in surface sediments from the western coast of the central Gulf, suggesting both higher coccolithophore production and better preservation, probably associated with lower diatom production. The coastal configuration and general more northwesterly direction of November-May winds off the eastern coast of the central Gulf (BandonDangon et al., 1991) favors coastal upwelling there.

\subsection{Increased ENSO cycles (2.8-2.4 ka)}

Fluctuations in $\mathrm{wt} \% \mathrm{Al}, \mathrm{Fe}$ and $\mathrm{Ti}$, proxies for terrigenous input, abruptly increase in amplitude at $\sim 2.6 \mathrm{ka}$ (Fig. 5), while the amplitude of biogenic silica and biologic productivity proxies $(\mathrm{Ba} /$ $\mathrm{Al}$ and $\mathrm{C}$-org/Al) increases noticeably at $\sim 2.4 \mathrm{ka}$ (Fig. 4). Octactis pulchra, a silicoflagellate indicative of high productivity in the modern Gulf, also increases markedly at $\sim 2.8 \mathrm{ka}$, possibly signaling the onset of modern coastal conditions in the Gulf. Taken together, these proxies suggest that climatic cycles, with an average periodicity of about $500 \mathrm{yr}$, between winter-dominated upwelling and diatom deposition and summer-dominated monsoonal terrigenous deposition increased in the latest Holocene between $\sim 2.8$ and $2.4 \mathrm{ka}$.

A late Holocene intensification of ENSO cycles (Clement et al., 2000) documented in coastal Peru 
after 3.2-2.8 ka (Sandweiss et al., 2001) may be responsible for the amplification of terrigenous vs. biosilica cycles seen in the Guaymas Basin. In the Cariaco basin off Venezuela, Haug et al. (2001) report evidence for increased ENSO variability between $\sim 3.8$ and $2.8 \mathrm{ka}$ based on increased amplitude in the wt $\% \mathrm{Fe}$ and $\mathrm{Ti}$ signals, which they consider to be proxies for precipitation input.

Biogenic silica and terrigenous cycles seem to occur every 500 yr (Figs. 4 and 5); however, higher resolution studies in nearby core BAM80 E-17 suggest that these cycles are closer to $200 \mathrm{yr}$ in length and that they may have a solar component (Barron et al., 2003a).

\section{Conclusions}

High resolution study of the geochemistry, diatoms, and silicoflagellates of the upper three cores of DSDP Site 480 reveals a complex record of paleoceanographic change in the eastern Guaymas Basin during the interval between 15.2 and $1.33 \mathrm{ka}$.

- During the Bølling-Allerød (14.6-12.9 ka), conditions were similar to those of today with laminated sediments enriched in biogenic silica (mostly diatoms). Diatom assemblages suggest that the summer monsoon was more prominent than it is today.

- The YD (12.9-11.6 ka) saw a major decline in biogenic silica. Diatom and silicoflagellate assemblages became more tropical in character and calcium carbonate increased dramatically. Rather than implying year round tropical conditions, it is likely that decreased upwelling of nutrient-rich waters characterized the YD.

- The early part of the Holocene between $\sim 11.6$ and $10 \mathrm{ka}$ was marked by gradually increasing biogenic silica and declining calcium carbonate content, as winter winds began shifting from a southeasterly to a more northwesterly direction. The near disappearance of the diatom Azpeitia nodulifera at $10.6 \mathrm{ka}$ and a permanent decline of $\mathrm{CaCO}_{3}$ below $5 \mathrm{wt} \%$ at $\sim 10 \mathrm{ka}$ signaled a rapid decline of tropical conditions in the central Gulf.

- The middle part of the Holocene between 10 and $6.2 \mathrm{ka}$ was characterized by minimal incursions of tropical waters into the central Gulf. Enhanced winter time northwest winds lead to increasing biogenic silica deposition and distinctive diatom and silicoflagellate assemblages were marked by the respective dominance of Roperia tesselata and Dictyocha stapedia, cosmopolitan subtropical taxa.

- At $\sim 6.2 \mathrm{ka}$, a stepwise increase in biogenic silica at DSDP 480 marked a possible regional shift in the direction late winter to early spring winds, causing enhanced coastal upwelling on the mainland side of the central Gulf. The return of Azpeitia nodulifera to diatom assemblages, indicated that occasional excursions of tropical waters into the central Gulf at this time began occurring during the late summer to early fall.

- Between $\sim 2.8$ and 2.4 ka modern oceanographic conditions with intensified ENSO cycles were established in the eastern Guaymas Basin. Spring upwelling increased after $2.8 \mathrm{ka}$ as indicated by the increased dominance of Octactis pulchra in silicoflagellate assemblages.

\section{Acknowledgements}

We are grateful to Constance Sancetta for sending use her raw sediment trap data and for helpful discussions. Anne Marie Harris and Robert Karlin shared their varve counts of DSDP 480 as well as a magnetic secular correlation of DSDP 480 that was critical for determining the chronology of Core 2. We also appreciate discussions and exchange of data with Lloyd Keigwin and Robert Douglas. Thanks are due to Jerry Bode of the Ocean Drilling Program (ODP) for locating and sending large-sized samples for AMS dating, to Tara Kneeshaw for her tireless efforts to pick foraminifera from these sediments, and to Jack McGeehin for his unsuccessful attempts to obtain enough carbon for AMS dating of these samples. Scott Starratt provided valuable research and editorial assistance. This research used samples and/ or data provided by the ODP. The ODP is sponsored by the U.S. National Science Foundation (NSF) and participating countries under the management of Joint Oceanographic Institutions, Inc. 
Scott Starratt and Walter Dean of the USGS provided very helpful reviews of the preliminary manuscript. We are grateful to Robert Douglas and Jere Lipps for their formal reviews of our paper.

\section{References}

Alley, R.B., Mayewski, P.A., Sowers, T., Stuiver, M., Taylor, K.C., Clark, P.U., 1997. Holocene climatic instability: A prominent, widespread event 8200 yr ago. Geology 25, 483-486.

Baba, J., Peterson, C.D., Schrader, H.J., 1991. Modern finegrained sediments in the Gulf of California. In: Dauphin, J.P., Simoneit, B.R.T. (Eds.), The Gulf and Peninsular Province of the Californias. Am. Assoc. Pet. Geol. Mem. 47, 569-587.

Bandon-Dangon, A., Dorman, C.E., Merrifield, M.A., Wianat, C.D., 1991. The lower atmosphere over the Gulf of California. J. Geophys. Res. 96, 16877-16896.

Barber, D.C., Dyke, A., Hillaire-Marcel, C., Jennings, A.E., Andrews, J.T., Kerwin, M.W., Bilodeau, G., McNeely, R., Southon, J., Morehead, M.D., Gagnon, J.-M., 1999. Forcing of the cold event of 8,200 years ago by catastrophic drainage of Laurentide lakes. Nature 400, 344-348.

Barron, J.A., Bukry, D., Bischoff, J.L., 2003a. A 2000-yr-long record of climate from the Gulf of California. In: West, G.J., Blomquist, N.L. (Eds.), Proceedings of the Nineteenth Pacific Climate Workshop, Asilomar, Pacific Grove, CA, March 3-6, 2002. Technical Report 71, Interagency Ecological Program for the San Francisco Estuary, Sacramento, CA, pp. 11-21. http://meteora.ucsd.edu/paclim/proceedings02.html.

Barron, J.A., Heusser, L., Herbert, T., Lyle, M., 2003b. High resolution climatic evolution of coastal northern California during the past 16,000 years. Paleoceanography, 18 (1), 10.1029/2002PA000768.

Bartlein, P.J., Anderson, K.H., Anderson, P.M., Edwards, M.E., Mock, C.J., Thompson, R.S., Webb, R.S., III, Whitlock, C., 1998. Paleoclimate simulations for North America over the past 21,000 years: Features of the simulated climate and comparisons with paleoenvironmental data. Quat. Sci. Rev. 17, 549-585.

Baumgartner, T.R., Christensen, N.C., Jr., 1985. Coupling of the Gulf of California to large-scale interannual climatic variability. J. Mar. Res. 43, 825-848.

Baumgartner, T.R., Ferreira-Bartrina, V., Moreno-Hentz, P., 1991. Varve formation in the central Gulf of California: A reconstruction of the origin of the dark laminae from the 20th Century varve record. In: Dauphin, J.P., Simoneit, B.R.T. (Eds.), The Gulf and Peninsular Province of the Californias. Am. Assoc. Pet. Geol. Mem. 47, 617-635.

Bischoff, J.L., Heath, G.R., Leinen, M., 1979. Geochemistry of deep-sea sediments from the Pacific manganese province. In:
Bischoff, J.L., Piper, D.Z. (Eds.), Marine Geology and Oceanography of the Pacific Manganese Nodule Province. Plenum, New York, pp. 397-436.

Clement, A.C., Seager, R., Cane, M.A., 2000. Suppression of El Niño during the mid-Holocene by changes in the Earth's orbit. Paleoceanography 15, 731-737.

Dean, W.E., Forester, R.M., Bradbury, J.P., 2002. Early Holocene change in atmospheric circulation in the Northern Great Plains: An upstream view of the $8.2 \mathrm{ka}$ cold event. Quat. Sci. Rev. 21, 1763-1775.

Dean, W.E., Gardner, J.V., Piper, D.Z., 1997. Inorganic geochemical indicators of glacial-interglacial changes in productivity and anoxia on the California continental margin. Geochim. Cosmochim. Acta 61, 4507-4518.

Diffenbaugh, N.S., Sloan, L.S., in press. Changes in mesoscale circulation drive seasonal responses of western North American climate to Mid Holocene orbital forcing. Holocene.

Douglas, R.G., Gorsline, D., Grippo, A., Granados, I., Gonzalez-Yajimovich, O., 2002. Holocene Ocean-Climate variations in Alfonso Basin, Gulf of California, Mexico. In: West, G.J., Buffaloe, L.D. (Eds.), Proceedings of the Eighteenth Pacific Climate Workshop, Asilomar, Pacific Grove, CA, March 18-21, 2001. Technical Report 68, Interagency Ecological Program for the San Francisco Estuary, Sacramento, CA, pp. 7-20.

Haug, G.H., Hughn, K.A., Sigman, D.M., Peterson, L.C., Röhl, U., 2001. Southward migration of the Intertropical Convergence Zone through the Holocene. Science 293, 1304-1308

Karlin, R., Levi, S., 1985. Geochemical and sedimentological control of magnetic properties of hemipelagic sediments. J. Geophys. Res. 90, 10373-10392.

Keigwin, L.D., 2002. Late Pleistocene-Holocene paleoceanography and ventilation of the Gulf of California. J. Oceanogr. 58, 421-432.

Keigwin, L.D., Jones, G.A., 1990. Deglacial climatic oscillations in the Gulf of California. Paleoceanography 5, 1009 1023.

Kemp, A.E.S., Pike, J., Pearce, R.B., Lange, C., 2000. The 'Fall dump' - a new perspective on the role of a 'shade flora' in the annual cycle of diatom production and export flux. Deep-Sea Res. II 47, 2129-2154.

Kennett, J.P., Ingram, B.L., 1995. A 20,000-year record of ocean circulation and climate change from the Santa Barbara Basin. Nature 377, 510-514.

Kienast, S.S., Calvert, S.E., Pedersen, T.F., 2002. Nitrogen isotope and productivity variations along the Northeast Pacific margin over the last $120 \mathrm{kyr}$ : Surface and subsurface paleoceanography. Paleoceanography 17(4).

Metcalfe, S.E., O’Hara, S.L., Caballero, M., Davies, S.J., 2000. Records of Late Pleistocene-Holocene climate change in Mexico - a review. Quat. Sci. Rev. 19, 699-721.

Mix, A.C., Lund, D.C., Pisias, N.G., Bodén, P., Bornmalm, L., Lyle, M., Pike, J., 1999. Rapid climate oscillations in the northeast Pacific during the last deglaciation reflect northern and southern hemisphere sources. In: Clark, P.U., Webb, R.S., Keigwin, L.D. (Eds.), Mechanisms for Global Climate 
Change at Millennial Time Scales. Am. Geophys. Monogr. 112, American Geophysical Union, Washington, DC, pp. $127-148$.

Murray, D., 1982. Paleo-Oceanography of the Gulf of California Based on Silicoflagellates from Marine Varved Sediments. Unpubl. M.Sc. Thesis, Oregon State University, $129 \mathrm{pp}$.

Murray, D., Schrader, H.J., 1983. Distribution of silicoflagellates in plankton samples from the Gulf of California. Mar. Micropaleontol. 7, 517-539.

Pike, J., Kemp, A.E.S., 1997. Early Holocene decadal-scale ocean variability recorded in Gulf of California laminated sediments. Paleoceanography 12, 227-238.

Poelchau, H.S., 1976. Distribution of Holocene silicoflagellates in North Pacific sediments. Micropaleontology 22, 164 193.

Pride, C., Thunell, R., Sigman, D., Keigwin, L., Altabet, M., Tappa, E., 1999. Nitrogen isotopic variations in the Gulf of California since the last deglaciation: Response to global climate change. Paleoceanography 14, 397-409.

Rhode, D., 2002. Early Holocene juniper woodland and chaparral taxa in the central Baja California Peninsula, Mexico. Quat. Res. 57, 102-108.

Sancetta, C., 1995. Diatoms in the Gulf of California: Seasonal flux patterns and the sediment record for the last 15,000 years. Paleoceanography 10, 67-84.

Sandweiss, D.H., Maasch, K.A., Burger, R.L., Richardson, J.B., III, Rollins, H.B., Clement, A., 2001. Variation in Holocene El Niño frequencies: Climate records and cultural consequences in ancient Peru. Geology 29, 603606.

Santamaria-del-Angel, E., Alavrez-Borrego, S., Muller-Karger, F.E., 1994. Gulf of California biogeographic regions based on coastal zone color scanner imagery. J. Geophys. Res. 99, 7411-7421.

Schrader, H., Baumgartner, T., 1983. Decadal variation of upwelling in the central Gulf of California. In: Thiede, J., Suess, E. (Eds.), Coastal Upwelling, Part 2. Plenum, New York, pp. 247-276.
Schrader, H., Pisias, N., Cheng, G., 1986. Seasonal variation of silicoflagellates in phytoplankton and varved sediments in the Gulf of California. Mar. Micropaleontol. 10, 207-233.

Shackleton, N.J., Hall, M.A., 1982. Oxygen isotope study of continuous scrape samples from Site 480. In: Curray, J.R., Moore, D.G., et al. (Eds.), Init. Rep. DSDP 64, pp. 12511254.

Shipboard Scientific Party, 1982. Guaymas Basin slope: Sites 479 and 480. In: Curray, J.R., Moore, D.G., et al. (Eds.), Init. Rep. DSDP 64, pp. 431-504.

Soto-Mardones, L., Marinone, S.G., Parés-Sierra, A., 1999. Time and spatial variability of sea surface temperature in the Gulf of California. Cienc. Mar. 25, 1-30.

Stuiver, M., Reimer, P.J., Bard, E., Beck, J.W., Burr, G.S., Hughen, K.A., Kromer, B., McCormac, F.G., van der Plicht, J., Spurk, M., 1998. INTCAL98 radiocarbon age calibration 24,000-0 cal BP. Radiocarbon 40, 1041-1083.

Thunell, R.C., 1998. Seasonal and annual variability in particle fluxes in the Gulf of California. A response to climate forcing. Deep-Sea Res. I 45, 2059-2083.

Thunell, R.C., Pride, C., Tappa, E., Muller-Karger, F., 1994. Varve formation in the Gulf of California: Insights from time series sediment trap and remote sensing. Quat. Sci. Rev. 12, 451-464.

Thunell, R.C., Pride, C., Ziveri, P., Muller-Karger, F., Sancetta, C., Murray, D., 1996. Plankton response to physical forcing in the Gulf of California. J. Plankton Res. 18, 2017-2026.

Van Devender, T.R., Burgess, T.L., Felger, R.S., Turner, R.M., 1990. Holocene vegetation of the Hornoday Mountains of northwestern Sonora, Mexico. Proc. San Diego Soc. Nat. Hist. 2, 1-19.

Verosub, K.L., Harris, A.H., Karlin, R., 2001. Ultrahigh-resolution paleomagnetic record from ODP Leg 169S, Saanich Inlet, British Columbia: Initial results. Mar. Geol. 174, 7993.

Ziveri, P., Thunell, R.C., 2000. Coccolithophore export production in Guaymas Basin, Gulf of California: Response to climate forcing. Deep-Sea Res. II 47, 2073-2100. 